\title{
Demonstration and Evaluation of the Pulsed Ultraviolet-Irradiation Gas-Treatment System, Savannah River Site
}

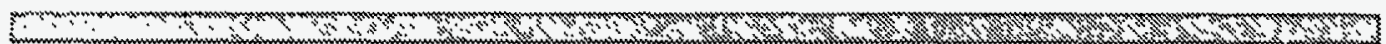

by J. Schneider, M. Wilkey, R. Peters, N. Tomczyk, J. Friedlund, P. Farber,

B. Mass, ${ }^{\star}$ and W. Haag*

Energy Systems Division,

Argonne National Laboratory, 9700 South Cass Avenue, Argonne, Illinois 60439

October 1994

Work sponsored by United States Department of Energy,

Volatile Organic Compounds Non-Arid Integrated Demonstration,

Environmental Restoration Demonstration, Testing, and Evaluation Division

"Mass and Haag are affiliated with Purus, Inc., San Jose, Califomia. 
This report is printed on recycled paper. 


\section{DISCLAIMER}

This report was prepared as an account of work sponsored by an agency of the United States Government. Neither the United States Government nor any agency thereof, nor any of their employees, make any warranty, express or implied, or assumes any legal liability or responsibility for the accuracy, completeness, or usefulness of any information, apparatus, product, or process disclosed, or represents that its use would not infringe privately owned rights. Reference herein to any specific commercial product, process, or service by trade name, trademark, manufacturer, or otherwise does not necessarily constitute or imply its endorsement, recommendation, or favoring by the United States Government or any agency thereof. The views and opinions of authors expressed herein do not necessarily state or reflect those of the United States Government or any agency thereof. 


\section{DISCLAIMER}

Portions of this document may be illegible in electronic image products. Images are produced from the best available original document. 


\section{Contents}

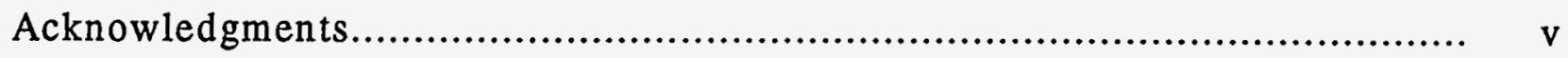

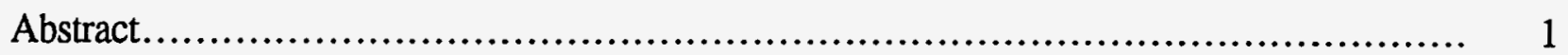

1 Introduction............................................................................. 1

2 Site Description and History .................................................... 3

3 Site Permit ......................................................................... 7

4 UV-Irradiation Test Equipment.................................................... 8

5 Process Description.............................................................. 10

5.1 Power Distribution .............................................................. 10

5.2 Computer and Controls .................................................... 10

5.3 Pulsed Irradiation System .................................................. 10

5.4 Lamp Cooling.................................................................. 12

5.5 Process Air Flow ........................................................ 12

6 Sampling Equipment and Procedures............................................. 13

7 Field Analytical Techniques..................................................... 15

7.1 SRS Analytical Techniques ................................................ 16

7.2 Lawrence Livermore National Laboratory Analytical Techniques......................... 17

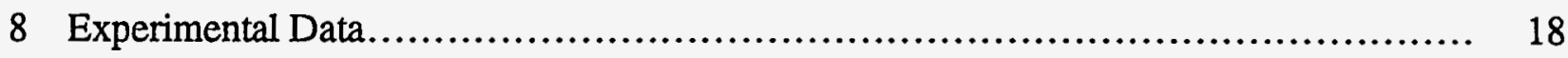

8.1 GC Analysis ............................................................ 18

8.2 Chemical Reactions of Primary and Secondary Contaminants................. 30

9 Economics of Purus System ....................................................... 32

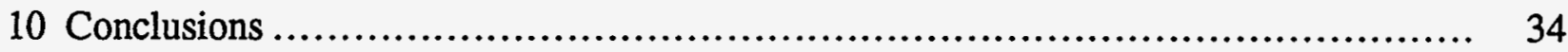

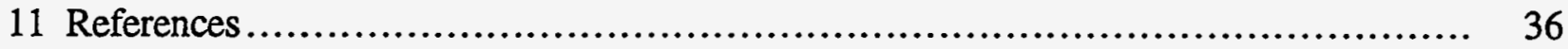

\section{Tables}

1 Experimental Test Matrix Used during Demonstration of the Pulsed UV-Irradiation Gas-Treatment Technology at the Savannah River Site.................. 11

2 Typical Work Day Test Sampling Schedule ...................................... 13

3 Targeted Analytes for Gas Samples Sent to SRTCADS ........................... 14

4 GC Area Counts for the 100-ppmv Standards.................................... 16 


\section{Figures}

1 Location of the SRS in South Carolina .......................................... 4

2 Detail of SRS Layout.......................................................... 5

3 Integrated Demonstration Site Test Well Location at A-014 Area

West of the 300-M Area of the Savannah River Site............................... 6

4 Purus UV-Irradiation System Setup................................................ 9

5 PCE, TCE, TCA, CT, and Chloroform for 1400-ppmv Nominal PCE

Concentration at 25-scfm Gas Flow Rate.........................................

6 PCE, TCE, TCA, CT, and Chloroform for 3100-ppmv Nominal PCE

Concentration at 25-scfm Gas Flow Rate.

7 PCE, TCE, TCA, CT, and Chloroform for 450-ppmv Nominal PCE

Concentration at 50-scfm Gas Flow Rate.

8 PCE, TCE, TCA, CT, and Chloroform for 5000-ppmv Nominal PCE

Concentration at 75-scfm Gas Flow Rate.

9 PCE, TCE, TCA, CT, and Chloroform for 4450-ppmv Nominal PCE

Concentration at 80-scfm Gas Flow Rate.

10 PCE, TCE, TCA, CT, and Chloroform for 800-ppmv Nominal PCE

Concentration at 100-scfm Gas Flow Rate.

11 PCE, TCE, TCA, CT, and Chloroform for $1 \mathrm{~Hz}$ at 600-ppmv Nominal

PCE Concentration

12 PCE, TCE, TCA, CT, and Chloroform for $15 \mathrm{~Hz}$ at $600-\mathrm{ppmv}$ Nominal PCE Concentration.

13 PCE, TCE, TCA, CT, and Chloroform for $20 \mathrm{~Hz}$ at $600-p p m v$ Nominal PCE Concentration.

14 PCE, TCE, TCA, CT, and Chloroform for $1 \mathrm{~Hz}$ at 6,000-ppmv Nominal PCE Concentration.

15 PCE, TCE, TCA, CT, and Chloroform for $5 \mathrm{~Hz}$ at 6,000-ppmv Nominal PCE Concentration.

16 PCE, TCE, TCA, CT, and Chloroform for $10 \mathrm{~Hz}$ at 6,000-ppmv Nominal PCE Concentration. 


\section{Acknowledgments}

The authors would like to gratefully acknowledge John Haselow, John Young, and Tim Jarosch, from the Westinghouse Savannah River Company, for all their efforts in preparing the Savannah River Site for our demonstration/evaluation and for all of their helpful interactions during the actual tests. The efforts of Jim Brucks of Purus, Inc., in operating the Purus system during testing at the Savannah River Site, especially his willing work with the Westinghouse Savannah River Company and Argonne National Laboratory personnel through frustrating times of rain and equipment problems, are greatly appreciated. We would also like to acknowledge the efforts of John Allen of Argonne National Laboratory in working with the field personnel to develop a meaningful health and safety plan for use at the off-site facility. Finally, we wish to acknowledge the very fine efforts of Robert Putnam in editing this document. 


\title{
Demonstration and Evaluation of the Pulsed Ultraviolet- Irradiation Gas-Treatment System, Savannah River Site
}

\author{
by \\ J. Schneider, M. Wilkey, R. Peters, N. Tomczyk, J. Friedlund, \\ P. Farber, B. Mass, and W. Haag
}

\begin{abstract}
Argonne National Laboratory was funded by the U.S. Department of Energy's Environmental Restoration Demonstration, Testing, and Evaluation Division to demonstrate and evaluate a pulsed ultraviolet-irradiation system developed by Purus, Inc., at the Volatile Organic Compounds Non-Arid Integrated Demonstration at the Savannah River Site near Aiken, South Carolina. The Purus system consists of four reactor chambers, each containing a xenon flash lamp. During the two weeks of testing, samples were taken and analyzed from the inlet and outlet sides of the Purus system. The contaminants of concern on the inlet were tetrachloroethylene (PCE), trichloroethylene (TCE), and 1,1,1-trichloroethane (TCA); the contaminants of concern on the outlet were PCE, TCE, TCA, carbon tetrachloride (CT), and chloroform. The evaluation of the Purus system included an examination of the reduction of both TCE and PCE and a search for any change in the concentrations. (Operating conditions included flow rates, ranging from 25 to 100 standard cubic feet per minute; inlet concentration of PCE, ranging from 360 to 10,700 parts per million volume; and flash lamp rates, ranging from 1 to 30 hertz.) The Purus system was quite efficient at reducing the concentrations of both PCE and TCE. The potential by-products, TCA, CT, and chloroform, showed no significant increases throughout the range of the various operating parameters. Overall, the Purus system appears to be a cost-efficient means of reducing the concentrations of $\mathrm{PCE}$ and TCE, while the removal of the initial photooxidation products and TCA is slower and needs further evaluation.
\end{abstract}

\section{Introduction}

Several different technologies were tested at the Savannah River Site (SRS) to remove volatile organic compounds (VOCs) from the subsurface environment. These VOCs were the by-product of past chemical spills, including pipeline breakage and rupture, which allowed different chemicals to enter the subsurface environment; these chemicals included tetrachloroethylene (PCE), trichloroethylene (TCE), and 1,1,1-trichloroethane (TCA). Chemicals that were discharged at the SRS in some cases reacted with subsurface soils in-situ to create additional VOCs. 
This continuing VOCs problem led the U.S. Department of Energy (DOE) to set up a series of integrated demonstration tests that used various gas-cleanup technologies. The current system used at the SRS is a thermal catalytic oxidation system. For the demonstration, however, a vacuum extraction system (VES) coupled with activated carbon adsorption was used. The VES process is considered to be the industry standard. Because of the high concentrations of PCE and TCE, the activated carbon tanks must be changed frequently. As a means of reducing the loading on the activated carbon tanks and as a means of reducing the toxicity and hazards associated with TCE and PCE, chemical oxidation systems were examined.

One chemical oxidation process used for gas treatment was the pulsed ultraviolet- (UV-) irradiation process, developed and manufactured by Purus, Inc., San Jose, California. This oxidation process uses pulsed UV irradiation as a means of destroying the influent VOCs (containing primarily TCE and PCE).

Argonne National Laboratory (ANL) was funded to demonstrate and evaluate the pulsed UV-irradiation treatment of the off-gases from the VES. The project was conducted jointly with Purus, Inc. 


\section{Site Description and History}

The Savannah River Site is a 310-square-mile facility owned by the DOE and operated under contract DE-AC09-89R180035 by the Westinghouse Savannah River Company. The site is near Aiken, South Carolina. Figure 1 shows the location of the SRS in South Carolina. Figure 2 shows a detail of the SRS layout. The site has been operated as a nuclear production facility for DOE since 1950. The production processes carried out over the past 40 years have generated considerable waste, resulting in the establishment of a number of waste sites. The sanitary landfill and other waste sites contain radiological wastes, heavy metals, organic solvents, and other types of mixed wastes. Many contaminated environments at the SRS have been identified, including both surface water and soils, subsurface sediment, and groundwater. Cleanup of these wastes and waste sites is a top priority of the DOE. Because of the large number of sites and large volume of contaminants at many of these sites, a considerable amount of time and money is required to complete the mandated cleanup.

The pulsed UV-irradiation process was tested at the test well location (A-014 area), located west of the 300-M area. Figure 3 shows the layout of the 300-M and 700-A areas, as well as the location of the test well at the A-014 area.

The 300-M area at the SRS was used to fabricate fuel and target elements that were later irradiated in SRS reactors. During these operations, the elements were degreased at several stages in the process. These degreasing operations generated large amounts of metal-degreasing solvent wastes. From 1952 to 1982 , the $M$ area generated an estimated 13 million pounds of chlorinated degreasing wastes (Hazen 1991, Marine and Bledsoe 1984). Evaporation alone accounted for a 50 to $95 \%$ loss, while the remainder went to the $M$-area process sewer system. Marine and Bledsoe (1984) estimated that as much as two million pounds may have been released to the sewer that led to the M-area settling basin; another one-and-a-half million pounds went directly to the A-014 area. Discharges to the M-area settling basin consisted primarily of TCE $(317,000 \mathrm{lb})$, PCE $(1,800,000 \mathrm{lb})$, and TCA $(19,000 \mathrm{lb})$. From 1952 to 1962, TCE was used; in 1962, the process at one of the facilities was changed and TCE was replaced by PCE, which was used until 1979; after 1979, TCA was used (Hazen 1991). By 1976, all discharges from the area were released directly into the $\mathrm{M}$-area settling basin. Solvents were detected in the groundwater below the M-area basin in 1981. Visual inspection of the terra cotta pipe in the process sewer line revealed cracks and root penetration; the pipe was relined in 1984 (Hazen 1991). The leaking process sewer line used to convey these wastes to the basin also released large quantities of the solvents into the surrounding vadose-zone sediments (Hazen 1991). The process sewer line was abandoned and removed in 1986.

The demonstration site for the pulsed UV-irradiation process was located at the A-014 area of the SRS. A well was sunk in order to reach the contaminated zone. 


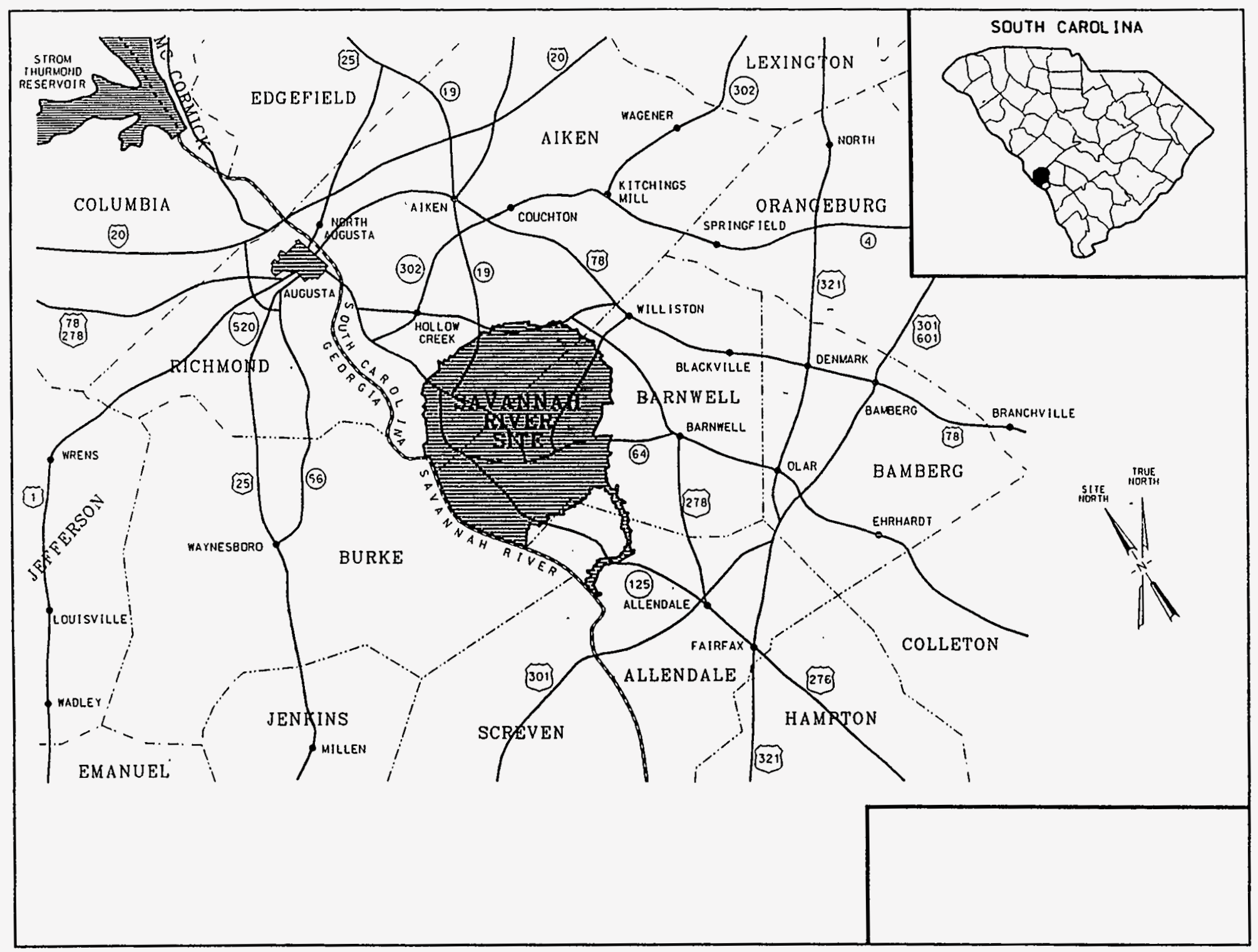

FIGURE 1 Location of the SRS in South Carolina 


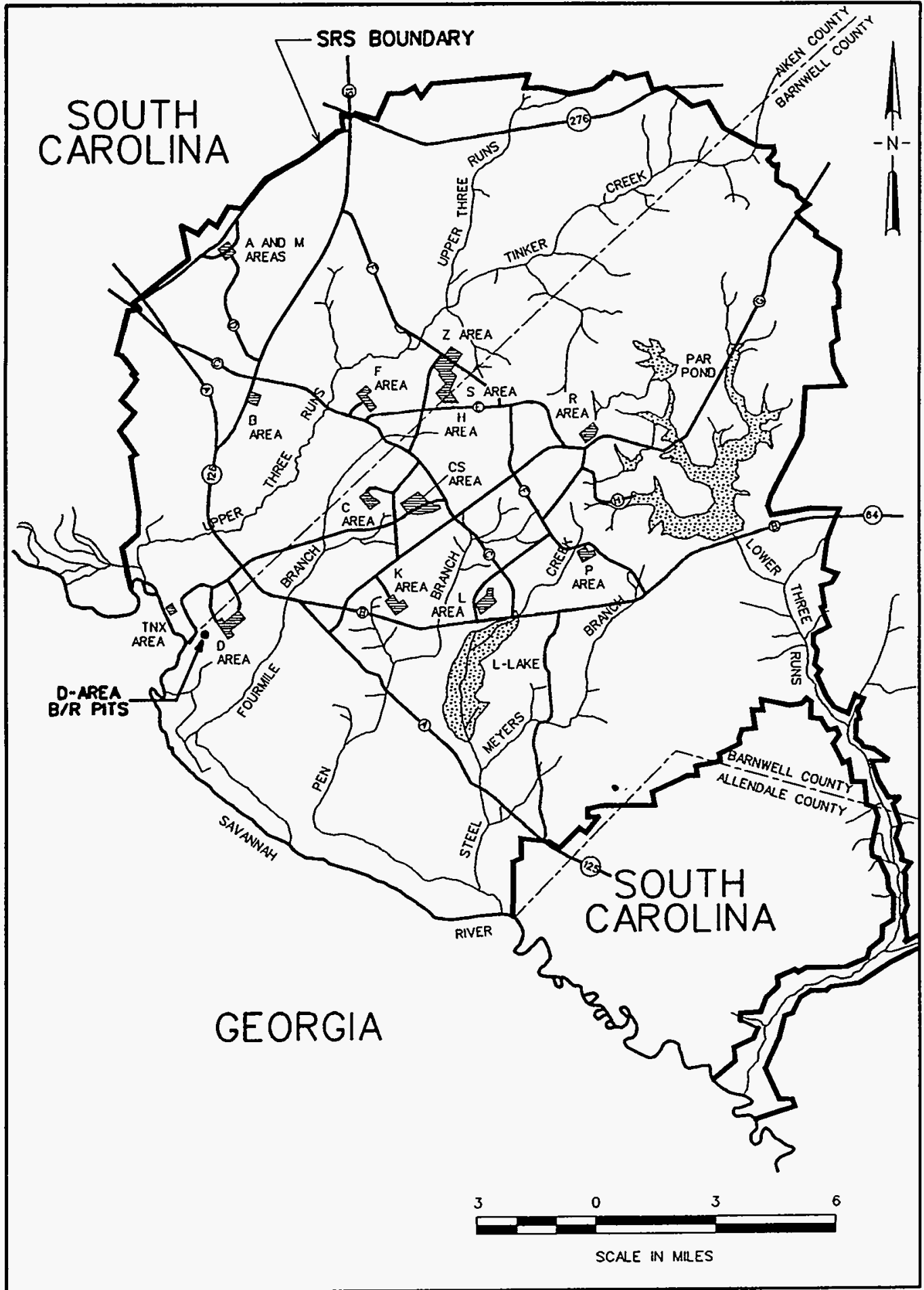

FIGURE 2 Detail of SRS Layout 


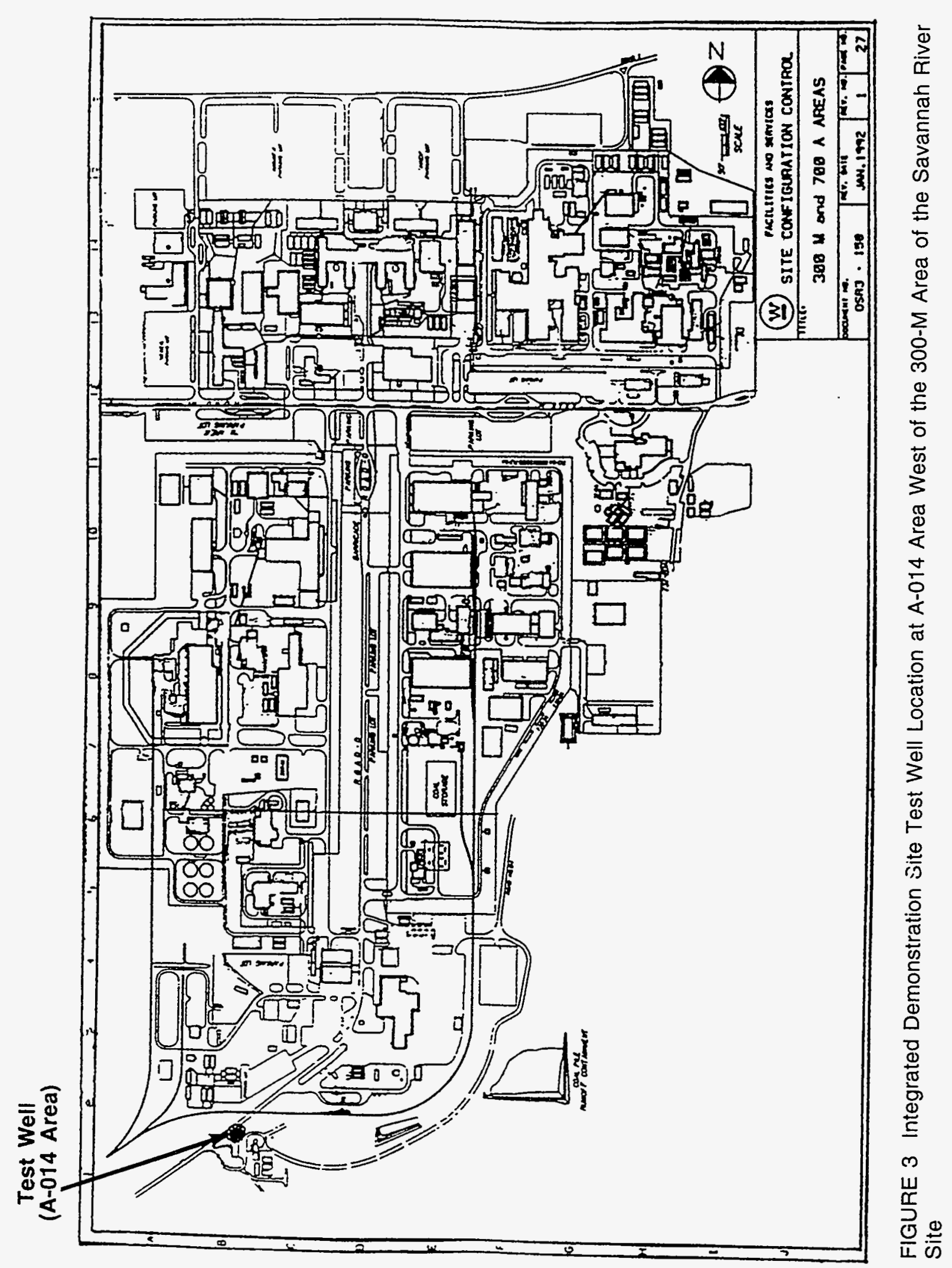




\section{Site Permit}

The Savannah River Site technical staff of the Westinghouse Savannah River Company applied for and received a permit from the South Carolina Department of Health and Environmental Control, Bureau of Air Quality Control, for the installation and operation of a mobile vacuum pump to extract volatile organic compounds from contaminated soil. The rated production was calculated in the permit at one gallon of liquid-phase condensate per day and $0.21 \mathrm{lb} / \mathrm{h}$ of volatile organic compounds in the vapor phase. The permit application states that the "granular activated carbon adsorption unit ... may be preceded by an innovative control technology." The calculated emission rates in the SRS permit are $4.15 \mathrm{lb} / \mathrm{h}$ for VOCs and $2.91 \mathrm{lb} / \mathrm{h}$ for $\mathrm{HCl}$ before the control device, $0.21 \mathrm{lb} / \mathrm{h}$ for VOCs and $2.91 \mathrm{lb} / \mathrm{h}$ for $\mathrm{HCl}$ after the control device. Applicable stack data from the permit include stack elevation, $15 \mathrm{ft}$ above ground; inside stack diameter, $0.5 \mathrm{ft}$; gas velocity, $43 \mathrm{ft} / \mathrm{s}$; temperature, $130^{\circ} \mathrm{F}$; and estimated moisture content, $40 \%$.

The permit allows around-the-clock testing for the integrated demonstration time period. All of the Purus pulsed UV-irradiation tests were conducted in a two-week period, March 23 to April 1, 1993.

All condensate and spent activated carbon are potentially subject to the South Carolina Hazardous Waste Management Act. 


\section{UV-Irradiation Test Equipment}

A vertical vacuum extraction well was installed in the vadose zone and was screened from a depth of 55-115 ft. A vacuum blower system, capable of pulling up to 500 standard cubic feet per minute (scfm), and a VES was installed, with the off-gases trapped on activated carbon beds before being vented to the atmosphere. The vacuum blower was modified with a valved manifold system to allow a stable side stream with a flow rate of approximately $5 \mathrm{scfm}$. A pipe was connected to the side stream for the UV-irradiation test equipment. The gas stream was saturated with water vapor. Concentrations of TCE ranged from 30 to $1,100 \mu \mathrm{L} / \mathrm{L}$, and concentrations of PCE ranged from 320 to $10,700 \mu \mathrm{L} / \mathrm{L}$, during the demonstration. Figure 4 shows the Purus UVirradiation system setup.

Purus transported the pulsed FP-3 UV-irradiation equipment to the SRS during the week of March 1-5, 1993. They assembled and checked out the system, then tested the equipment during the week of March 8-12, in advance of conducting the test demonstration.

The UV-irradiation equipment was hooked up to the side-stream pipe. Air was extracted from the contaminated zone by means of the VES and passed through the pulsed UV-irradiation system. The UV-irradiation system was designed to convert most of the chlorinated organic compounds into hydrogen chloride $(\mathrm{HCl})$, carbon dioxide $\left(\mathrm{CO}_{2}\right)$ gas, and chlorine $(\mathrm{Cl})$ gas. Argonne National Laboratory staff sampled and analyzed the influent (inlet) and effluent (outlet) gases for targeted chlorinated volatile organics, including TCE, PCE, TCA, chloroform $\left(\mathrm{CHCl}_{3}\right)$, and carbon tetrachloride (CT). Intermediate by-product gases were also analyzed to check for the presence of such materials as phosgene (dichlorocarbonyl or DCC) and dichloroacetic acid (DCAA). The exhaust gases from the pulsed UV-irradiation process were vented to a granular activated-carbon treatment unit before being discharged into the atmosphere. 


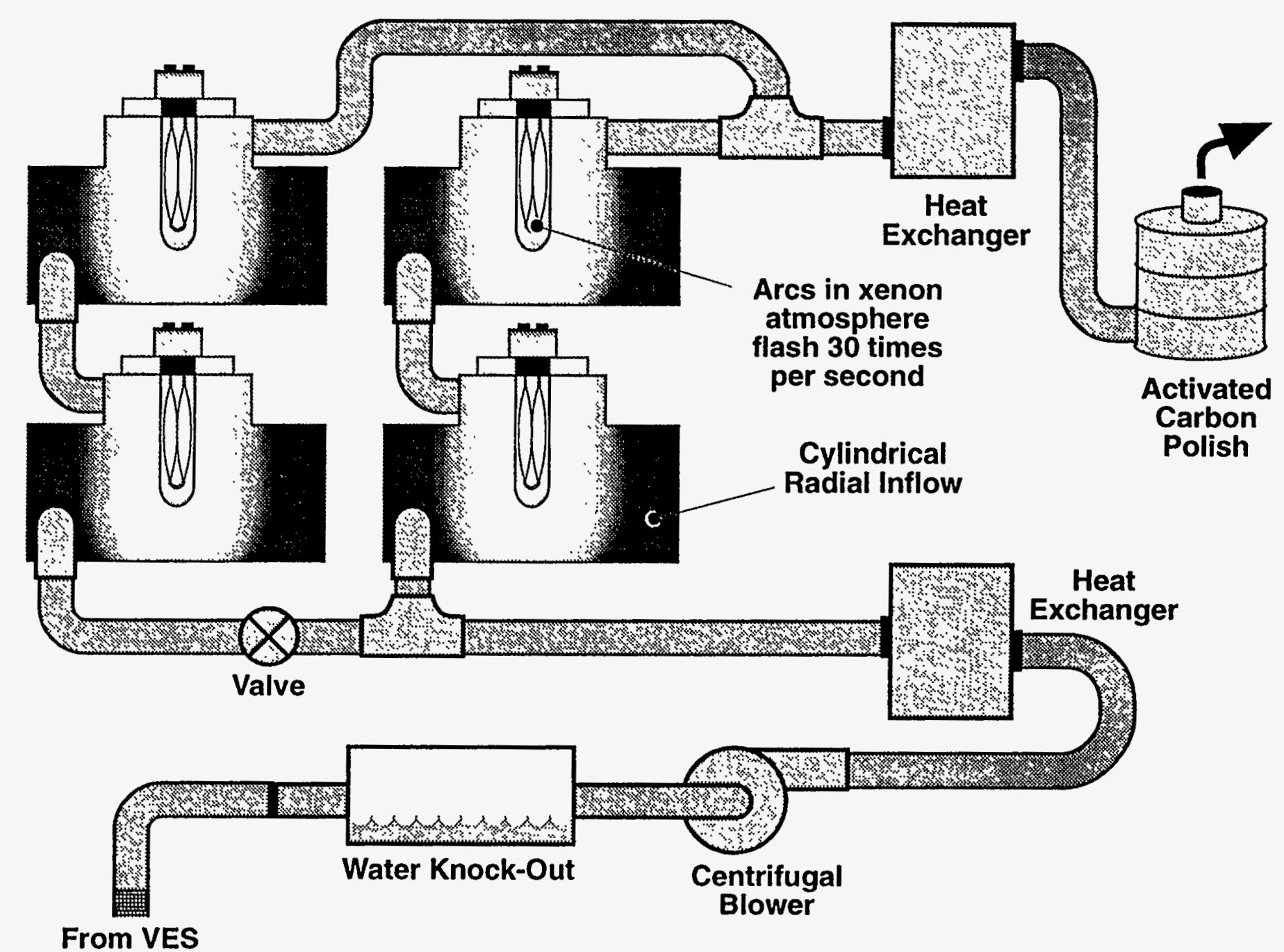

FIGURE 4 Purus UV-Irradiation System Setup 


\section{Process Description}

The Purus pulsed UV-irradiation system used at SRS consists of five basic subsections: (1) power distribution, (2) computer and controls, (3) pulsed irradiation system, (4) lamp cooling, and (5) process air flow.

\subsection{Power Distribution}

The power distribution system, housed in a NEMA 12 enclosure located at one end of the UV-irradiation unit, is designed to accept 208-volt (V), 100-ampere (A) service. Circuit breakers and high-power contactors, necessary for safe operation of the equipment, are contained within the enclosure. Wiring from this module carries power to the other components in the unit.

\subsection{Computer and Controls}

The UV-irradiation equipment is controlled by a personal computer based on a 386 microprocessor. The computer is connected via a 55-ft-long, 50-conductor ribbon cable to a subchassis containing circuitry configured from components available from the Opto $22 \mathrm{Co}$. These circuits provide optical isolation between the computer and the various power components and sensors needed for operation. During the demonstration at the SRS, the computer was placed adjacent to the UV-irradiation unit.

By use of the menu-driven operator interface, it is possible to select which and how many of the four flash lamps operate and to set the flash rate (hence the power level) for the system. This allows the operator to vary the average power delivered to the gas being treated. Any or all of the flash lamps may be enabled, and the flash rate may be set between 1 and $30 \mathrm{hertz}(\mathrm{Hz})$.

\subsection{Pulsed Irradiation System}

The UV-irradiation unit uses four xenon flash lamps to generate high-intensity bursts of deep-UV light. The lamps have a high-power density with maximum output at 230 nanometer $(\mathrm{nm})$ and substantial emission as low as $200 \mathrm{~nm}$; therefore, they are able to initiate direct photolysis of VOCs better than other UV-systems that have emission maxima at or above $254 \mathrm{~nm}$. Each lamp is physically, mechanically, and electrically independent of the other three; however, in this system the lamps are controlled by common circuitry and software, so for any specific separate test they all operate at the same voltage and flash rate.

Operation of a xenon flash lamp, to optimize the UV output and lifetime, requires a highvoltage trigger pulse - typically in the 20-kilovolt $(\mathrm{kV})$ range - to electrically break down the normally nonconductive gas in the lamp and a low, controlled current source (simmer) to provide 
the voltages and current necessary to carry the lamp from this initial conductive state to the proper interpulse operating condition. The high-voltage trigger pulse is generated by a separate power module and is connected by a high-voltage feed through to a tungsten wire located in close proximity to the flash lamp. The Purus system operates the lamps at $3 \mathrm{~A}$ of simmer, with a resultant voltage of $130 \mathrm{~V}$. This is provided by a switching power supply with a minimum efficiency of $80 \%$. Four such simmer supply modules are contained within the UV-irradiation unit and are connected to the flash lamps via the pulse-forming network ( $P F N$ ).

The PFN contains high-voltage energy storage capacitors, high-voltage isolation diodes, fast-switching thyristors, and various power resistors and capacitors, as needed, to ensure proper voltage distribution. The high-voltage energy storage capacitors used in the UV-irradiation unit have a capacitance of 20 microfarads $(\mu \mathrm{F})$ and are operated at 3,500 V. Under these conditions, they store 122.4 joules $(J)$ of energy. This energy is discharged into the flash lamp on each flash. Therefore, when the lamps are operated at $30 \mathrm{~Hz}$ ( 30 flashes per second), the power input to the lamps is $122.5 \mathrm{~J}$ times $30 \mathrm{~Hz}$, or 3,675 watts (W). The capacitors are charged by specially designed, commercially available capacitor-charging power supplies rated by the manufacturer at $90 \%$ efficiency. Purus has determined that this particular combination of capacitance and voltage is optimally matched with the mechanical and electrical characteristics of the xenon flash lamp for the photolysis of materials being treated in this study.

Table 1 shows the number of xenon flash lamps used at different influent gas concentrations in parts per million volume (ppmv) and at different pulse rates. For any one test, the lamps are all set at the same pulse rate.

TABLE 1 Experimental Test Matrix Used during Demonstration of the Pulsed UV-Irradiation Gas-Treatment Technology at the Savannah River Site

\begin{tabular}{|c|c|c|c|c|c|c|c|c|c|c|c|c|c|c|}
\hline \multirow[b]{2}{*}{$\begin{array}{l}\text { Flow } \\
\text { (scfm) }\end{array}$} & \multirow{2}{*}{$\begin{array}{l}\text { Concentration } \\
\text { Range of PCE } \\
\text { (ppmv) }\end{array}$} & \multirow{2}{*}{$\begin{array}{l}\text { No. Xenon } \\
\text { Flash Lamps } \\
\text { Used }\end{array}$} & \multicolumn{12}{|c|}{ Pulse Rate $(\mathrm{Hz})$} \\
\hline & & & 0 & 1 & 2 & 3 & 4 & 5 & 10 & 15 & 17 & 20 & 25 & 30 \\
\hline 25 & $580-980$ & 4 & & $x$ & & $x$ & & $x$ & $x$ & & & & & \\
\hline 25 & $1,260-1,440$ & 4 & & $x$ & & & & $x$ & $x$ & $x$ & & $x$ & $x$ & $x$ \\
\hline 25 & $3,050-3,490$ & 4 & & $x$ & & & & $x$ & $x$ & $x$ & & $x$ & $x$ & $x$ \\
\hline 37.5 & $700-800$ & 2 & & $x$ & & $x$ & & $x$ & $x$ & $x$ & & $x$ & $x$ & $x$ \\
\hline 50 & $360-500$ & 4 & & $x$ & & & & $x$ & $x$ & $x$ & & $x$ & $x$ & $x$ \\
\hline 50 & $490-530$ & 2 & & & $x$ & $x$ & $x$ & & & & & & & \\
\hline 50 & $7,910-10,700$ & 4 & $x$ & $x$ & & & & $x$ & & & & & & $x$ \\
\hline 60 & $450-470$ & 2 & & $x$ & & $x$ & & $x$ & $x$ & $x$ & & $x$ & & \\
\hline 75 & $470-580$ & 2 & & $x$ & & $x$ & & $x$ & $x$ & $x$ & $x$ & $x$ & $x$ & $x$ \\
\hline 75 & $4,390-5,830$ & 4 & & $x$ & & & & $x$ & $x$ & $x$ & & $x$ & & \\
\hline 80 & $560-4,400$ & 4 & $x$ & $x$ & & & & $x$ & $x$ & $x$ & & $x$ & & \\
\hline 100 & $520-710$ & 4 & & $x$ & & $x$ & & $x$ & $x$ & $x$ & & $x$ & & \\
\hline
\end{tabular}




\subsection{Lamp Cooling}

Each xenon flash lamp is housed in an ultra-high-purity quartz sleeve. Deionized water is made to flow around the lamp to provide cooling. The lamp envelope is $5 \mathrm{~mm}$ in diameter, and the arc is $150 \mathrm{~mm}$ long. The surface area is approximately $2,400 \mathrm{~mm}^{2}$. At a power input of $3,675 \mathrm{~W}$, and assuming $70 \%$ efficiency in the transfer of energy stored in the PFN to the lamp, the power density on the lamp's surface is $873 \mathrm{~W} / \mathrm{m}^{3}$. At such a high loading, it is essential that the lamp be water-cooled or the envelope would heat to the point where the quartz would soften and deform, leading to lamp failure. Since the lamp electrodes are immersed in the cooling water, deionized water must be used. Light from the lamp passes through the high-purity water and the quartz sleeve into the photochemical reaction chamber.

The deionized water is contained in a central reservoir and pumped to all of the lamps, in parallel, by an electric water pump. The water is recycled, passing through a deionized bed, a particulate filter, and a heat exchanger. At most sites, adequate cooling water is available for use in the heat exchanger. When it became clear that a cooling source would not be available during testing at the SRS, Purus made a last-minute change and added a closed-loop refrigeration system for cooling. Some difficulties were experienced on-site in getting the improvised cooling system to operate well enough to allow for continuous full-power operation.

\subsection{Process Air Flow}

Each of the four flash lamps in the system is housed in its own photochemical reaction chamber. The process air flows into the UV-irradiation system via a 3-in. PVC pipe and goes to a tee, which splits the flow into two equivalent paths. One path contains a ball valve just prior to the reaction chambers, which allows isolation of that path. Each path then goes to two reaction chambers in series (see Figure 4). In any test, all flash lamps operate under the same conditions; however, it is possible to disconnect any lamp (or lamps) in the system so that it does (they do) not flash. Therefore, it is possible to configure the system for the process air to pass through one, two, or four operational photochemical reactors and flash lamps. This gives some flexibility in setting the residence time in the system. (Because of balancing requirements, a three-lamp configuration was not used.)

Because of time constraints during the tests, only selected flow rates and pulse-rate values were run. Table 1 shows the flow rates used for the experiment and the concentration ranges of PCE. 


\section{Sampling Equipment and Procedures}

In all cases, during sampling and testing, appropriate personal protective equipment (Class C) was worn. Equipment included safety glasses, respirators, safety shoes (with steel toes), and impervious gloves (required when taking samples). Every attempt was made to avoid contact of the gas streams with eyes, skin, and clothing.

On the site, a typical test schedule for sampling was followed each day. Table 2 shows a typical test schedule for a work day.

Gas samples were collected by using one-liter Tedlar ${ }^{\circledR}$ bags. Duplicate bag samples were submitted to the Savannah River Technology Center Analytical Development Section (SRTCADS) for analysis using the purge-and-trap gas chromatograph (GC). Syringe samples of effluent vapor were taken by ANL from the bags for immediate determination of PCE, TCE, TCA, and $\mathrm{CCl}_{4}$ concentrations by $\mathrm{GC}$ techniques.

The joint VES/UV-irradiation system was allowed to come to steady state, after making any operational changes, before any samples were collected. To monitor the system performance, a

TABLE 2 Typical Work Day Test Sampling Schedule

\begin{tabular}{llll}
\hline Time & \multicolumn{1}{c}{ Event } & No. of Samples & \multicolumn{1}{c}{ Data } \\
\hline 0800 & Arrive at site & None & None \\
0900 & Start and set gas flow rate & 1 -inlet/1-outlet & $\begin{array}{l}\text { Gas temperature and pressure, gas flow } \\
\text { rate }\end{array}$ \\
0930 & Energize lamps & None & $\begin{array}{l}\text { Gas temperature and pressure, gas flow } \\
\text { rate, and lamp power and pulse rate }\end{array}$ \\
1000 & Start run (1 Hz) & 1 -inlet/1-outlet & Same as above \\
1100 & $5 \mathrm{~Hz}$ & 1 -inlet/1-outlet & Same as above \\
1200 & $10 \mathrm{~Hz}$ & 1 -inlet/1-outlet & Same as above \\
1300 & $15 \mathrm{~Hz}$ & 1 -inlet/1-outlet & Same as above \\
1400 & $25 \mathrm{~Hz}$ & 1 -inlet/1-outlet & Same as above \\
1500 & $30 \mathrm{~Hz}$ & 1 -inlet/1-outlet & Same as above \\
1600 & Deenergize lamps & 1 -inlet/1-outlet & Same as above \\
1700 & Shut down system & None & None \\
\hline & & & \\
\hline
\end{tabular}


minimum of five air volumes was passed before any samples were collected. One-liter samples were collected from both the influent (inlet) and effluent (outlet) streams. Table 3 lists the target analytes for gas samples. Bag samples of targeted compounds (TCE, PCE, TCA, and CT) were taken for intermediate analysis at the demonstration site. Compounds were analyzed by GC techniques at the SRS laboratory/trailer located approximately one mile away. Paul Daley, from Lawrence Livermore National Laboratory, also collected outlet samples in conjunction with this demonstration to determine whether and which degradation products were present in this processing.

Liquid samples were collected from condensate at the bottom of the activated-carbon tanks. These samples were used to check for potential degradation products (such as DCAA, dichloroacetylchloride [DCAC], and DCC).

The Tedlar ${ }^{\circledR}$ bags were filled with vapor samples from hoses on the influent (inlet) line to the experimental UV-irrigation system, and from the effluent (outlet) line after irradiation by the four lamps. All bags were filled and purged three times before the final sample was taken. The bags, if not analyzed immediately, were stored in a gray polyethylene bag and kept out of direct sunlight in a shed next to the UV system.

TABLE 3 Targeted Analytes for Gas Samples Sent to SRTCADSa

- Vinyl chloride

- Chloroethane

- 1,1-Dichloroethane

- Dichloromethane

- trans-1,2-Dichloroethene

- 1,1-Dichloroethane

- Methylchloroformate/phosgene derivative

- cis-1,2-Dichloroethene

- Chloroform

- 1,1,1-Trichloroethane (TCA)

- 1,2-Dichloroethane

- Carbon tetrachloride

- Benzene
- 1,4-Difluorobenzene

- Trichloroethylene (TCE)

- Toluene-ds (surrogate)

- Toluene

- 1,1,2-Trichloroethane

- Tetrachloroethylene (PCE)

- 1,1,1,2-Tetrachloroethane

- Chlorobenzene-d5

- 1,1,2,2-Tetrachloroethane

- 4-Bromofluorobenzene (surrogate)

- Pentachloroethane

- Hexachlorosthane

a Quantitative reporting limits $=1$ microgram/liter ( $\mu \mathrm{g} / \mathrm{L})$ for each analyte. 


\section{Field Analytical Techniques}

The instrument used for analysis of the vapor was a Hewlett Packard 5890 Series II GC with an electron capture detector (ECD). (A $60-\mathrm{m}$ by $0.75-\mathrm{mm}$-inside-diameter glass Vokal column with a 1.5 micron film thickness was used.) Most of the samples run on this GC were outlet samples. Most of the inlet samples were analyzed by a company called Ecova, Inc., an SRS contractor that had a Hewlett Packard $5890 \mathrm{GC}$ with a flame ionization detector (FID). (Again, a $15-\mathrm{m}$ by $0.32-\mathrm{mm}$ DB-5GC column was used.) The values they reported were used for inlet concentration values.

The GC/ECD was calibrated by using standard mixtures run first thing in the morning and then periodically throughout the day. (The standard mixture [supplied by Curtin Matheson, Inc.] came premixed in gas cylinders that were kept outside the analytical laboratory/trailer.) The compounds in the gas standard mixtures were $\mathrm{CHCl}_{3}, \mathrm{TCE}$, and PCE at concentrations of $10 \mathrm{ppmv}, 100 \mathrm{ppmv}$, and 1,000 ppmv. The standards used were gravimetric standards; that is, they were added by weight of the compound to give a per-volume concentration. Curtin Matheson did not certify the standards for accuracy, so the analysts at SRS verified the standards by comparison with a separate liquid standard. The results were within $5 \%$ of the concentrations stated for each standard.

Table 4 shows the responses of the 100-ppmv standard $\mathrm{CHCl}_{3}, \mathrm{TCE}$, and PCE for a $300-\mu \mathrm{L}$ injection. The date of the injection, the mean, standard deviation, and percent error are also given.

Three-hundred-microliter injections of the 10-ppmv and the 100-ppmv standards were used to calculate response factors and, ultimately, concentrations of TCE, $\mathrm{PCE}$, and $\mathrm{CHCl}_{3}$. The integration of the 10-ppmv standard was unreliable. Therefore, the area counts produced by the 100-ppmv standards were used to calculate the response factors and, ultimately, the TCE and the PCE concentrations. The inlet concentration was increased three times during the second week. This was achieved by decreasing the amount of air that was brought in with the vapor coming from the well. Because of this, $30 \mu \mathrm{L}$ of the 1,000-ppmv standard was used, along with $300 \mu \mathrm{L}$ of the 100-ppmv standard. The syringes used were Hamilton Gastight Series 1700 fixed-needle syringes, serial numbers 13-684-106 $(500 \mu \mathrm{L})$ and $14-824-30(50 \mu \mathrm{L})$.

For most of the samples, $300 \mu \mathrm{L}$ of sample was injected into the GC. For the higher inlet concentration samples, $30 \mu \mathrm{L}$ was injected. Because the instrument used for the outlet samples had to be shared, some bags had to wait to be analyzed, remaining in polyethylene bags until analysis. All the outlet samples were analyzed on the day of sampling. Because of the work load that Ecova had, some of the inlet samples were not analyzed for one to two days. Some higher inlet concentration data, therefore, are considered suspect as a result of the time delay. (This relates specifically to Table 1 concentrations above 1,000 ppmv.) 
TABLE 4 GC Area Counts for the 100-ppmv Standards

\begin{tabular}{|c|c|c|c|}
\hline \multirow[b]{2}{*}{ Date (1993) } & \multicolumn{3}{|c|}{ Area Counts } \\
\hline & $\mathrm{CHCl}_{3}$ & TCE & PCE \\
\hline 23 March & 34,107 & 73,828 & 419,962 \\
\hline 24 March & 35,696 & 78,079 & 419,073 \\
\hline 24 March & 36,280 & 76,997 & 415,292 \\
\hline 25 March & 34,347 & 78,827 & 468,926 \\
\hline 26 March & 36,522 & 78,125 & 405,231 \\
\hline 26 March & 34,075 & 79,754 & 378,187 \\
\hline 26 March & 32,869 & 75,143 & 373,399 \\
\hline 27 March & 35,399 & 75,503 & 381,141 \\
\hline 27 March & 35,303 & 75,945 & 407,495 \\
\hline 28 March & 36,262 & 79,822 & 439,303 \\
\hline 28 March & 34,100 & 74,797 & 415,643 \\
\hline 28 March & 27,640 & 69,713 & 409,598 \\
\hline 29 March & 32,143 & 64,822 & 356,216 \\
\hline 29 March & 33,101 & 70,334 & 358,052 \\
\hline 29 March & 36,980 & 79,204 & 490,851 \\
\hline 29 March & 35,888 & 80,594 & 501,499 \\
\hline 30 March & 40,171 & 87,237 & 472,018 \\
\hline 31 March & 32,113 & 69,132 & 377,270 \\
\hline 1 April & 34,434 & 74,198 & 426,504 \\
\hline 1 April & 32,888 & 69,749 & 421,298 \\
\hline 1 April & 25,474 & 75,834 & 435,845 \\
\hline Mean & 34,085 & 75,559 & 417,750 \\
\hline Standard Deviation & 3,142 & 4,936 & 40,626 \\
\hline$\%$ Error & $12.3 \%$ & $8.6 \%$ & $11.6 \%$ \\
\hline
\end{tabular}

The used Tedlar ${ }^{(8)}$ bags were purged by a vacuum pump before they were taken back to the site. The production of hydrochloric acid ( $\mathrm{HCl})$ vapors, however, caused the metal hardware on the bags to corrode. This was evidenced by the green sheen the metal took on and by the stain on the part of the bag that came in contact with the metal. It was discovered, after using some of these bags, that they did not retain their integrity and began to flatten during the trip from the site to the trailer. The data produced from gas contained in these bags are viewed as questionable and were not used in any of our report calculations.

\subsection{SRS Analytical Techniques}

Samples were also analyzed by John Young's lab at the SRS. He was given bags of vapor taken from the outlet and water samples. The water samples were acquired by placing water in a 
volatile organic acid vial and bubbling vapor through the water. The bubbling was performed for 4,8 , and 12 minutes. The water was analyzed for DCAA and DCAC. The vapor was analyzed for by-products of the reduction of PCE and TCE.

The vapor samples were concentrated by means of an OI Analytical model 4460A Dynamic Head space concentrator (purge and trap) using a three-stage trap. The instrument used was a Hewlett Packard GC 5890 series II with a 5971 quadrupole mass spectrometer. Internal standards and recovery surrogates were added per the U.S. Environmental Protection Agency Contract Laboratory Program Statement of Work 8-91. The mass spectrometer was tuned within 12 hours prior to each measurement, using p-bromofluorobenzene. The tuning verification was performed against both Resource Conservation and Recovery Act-Solid Waste RCRA SW-846 and the Contract Laboratory Program tuning requirements.

The water samples were analyzed by the SRTCADS method 2306, using ion chromatography. This is the standard anion chromatography method, which employs the suppressed conductivity detector.

\subsection{Lawrence Livermore National Laboratory Analytical Techniques}

Paul Daley, from Lawrence Livermore National Laboratory (LLNL), was also present during the second week of operations. He took strictly outlet samples. Vapor was passed through a Tenax ${ }^{\circledR}$ trap and then desorbed into a GC. The samples were derivatized before analysis. (The LLNL data are presented in a separate report.) 


\section{Experimental Data}

Data were collected during a two-week period, from March 23 to April 1, 1993. For a given inlet concentration, temperature, and pressure, several pulse rates (typically $1,5,10,15,20$, 25 , and $30 \mathrm{~Hz}$ ) were used. Table 1 gives the actual experimental test matrix. During the first week, the Purus unit encountered electrical problems, and the tests were run using only two of the four xenon flash lamps. During the actual sampling procedure, partial face masks were used by those personnel sampling at the outlet port (gases coming from the Purus unit) to counteract any of the anticipated by-products $\left(\mathrm{HCl}, \mathrm{Cl}_{2}\right.$ gas, and $\left.\mathrm{DCC}\right)$. The gas samples were tested by using GC analysis. The data that were collected and derived from the GC analyses are shown in Figures 5 through 16. Additionally, during the second week, a series of water samples were taken by Paul Daley to search for the presence of DCC, DCAC, and DCAA. The chemical equations that represent the reactions taking place, including intermediate products and byproducts, are presented in Section 8.2 .

\subsection{GC Analysis}

Figure 5 shows that at an inlet concentration of $1400 \mathrm{ppmv}$ for PCE and with a 25-scfm gas flow rate, both the TCE and PCE are effectively destroyed at all of the flash-lamp rates $(1-30 \mathrm{~Hz})$. The outlet TCA concentration drops off steadily in the $1-$ to $20-\mathrm{Hz}$ range and levels off at from 20 to $30 \mathrm{~Hz}$. The CT concentration rises slightly throughout the $1-$ to $30-\mathrm{Hz}$ range. The chloroform concentration drops off in the $1-$ to $10-\mathrm{Hz}$ range and remains at a low level at from 10 to $30 \mathrm{~Hz}$.

Figure 6 is similar to Figure 5, but it shows results at a higher inlet concentration (nominally $3100 \mathrm{ppmv}$ ). At only $1 \mathrm{~Hz}$, about $95 \%$ of the inlet concentrations of both the TCE and PCE are destroyed. At $5 \mathrm{~Hz}$ and beyond, both the TCE and PCE are effectively destroyed at all of the flash-lamp rates. The outlet TCA concentration drops off gradually as the flash-lamp rate increases to $30 \mathrm{~Hz}$. The $\mathrm{CT}$ concentration rises slightly throughout the $1-$ to $30-\mathrm{Hz}$ range. The chloroform concentration increases in the $1-$ to $10-\mathrm{Hz}$ range but drops off to a very low level beyond $10 \mathrm{~Hz}$.

Figure 7 shows that at an inlet concentration of $450 \mathrm{ppmv}$ for PCE and with a 50-scfm gas flow rate, both the TCE and PCE are effectively destroyed at all of the flash-lamp rates above $3 \mathrm{~Hz}$. The outlet TCA concentration remains steady in the $1-$ to $5-\mathrm{Hz}$ range and then drops off steadily in the range of 5 to $30 \mathrm{~Hz}$. The CT concentration rises slightly throughout the $5-$ to $15-\mathrm{Hz}$ range. The chloroform concentration increases over the $1-$ to $30-\mathrm{Hz}$ range.

Figure 8 shows that at an inlet concentration of 5000 ppmv for PCE and with a 75-scfm gas flow rate, both the TCE and PCE are effectively destroyed at all of the flash-lamp rates beyond $5 \mathrm{~Hz}$. At the $1-\mathrm{Hz}$ level, about $78 \%$ of the PCE is destroyed and about $55 \%$ of the TCE is destroyed. The outlet TCA concentration remains steady in the $1-$ to $5-\mathrm{Hz}$ range, drops off steadily 


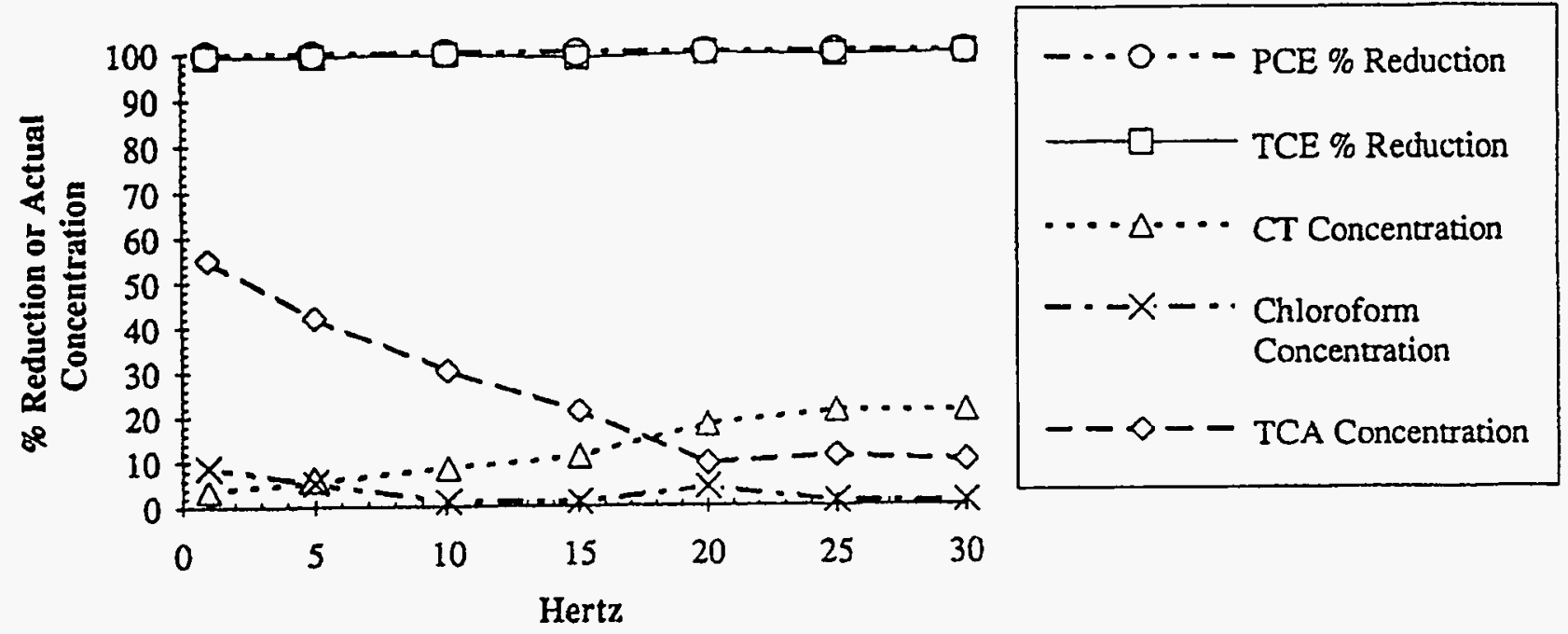

FIGURE 5 PCE, TCE, TCA, CT, and Chloroform for 1400-ppmv Nominal PCE Concentration at 25-scfm Gas Flow Rate

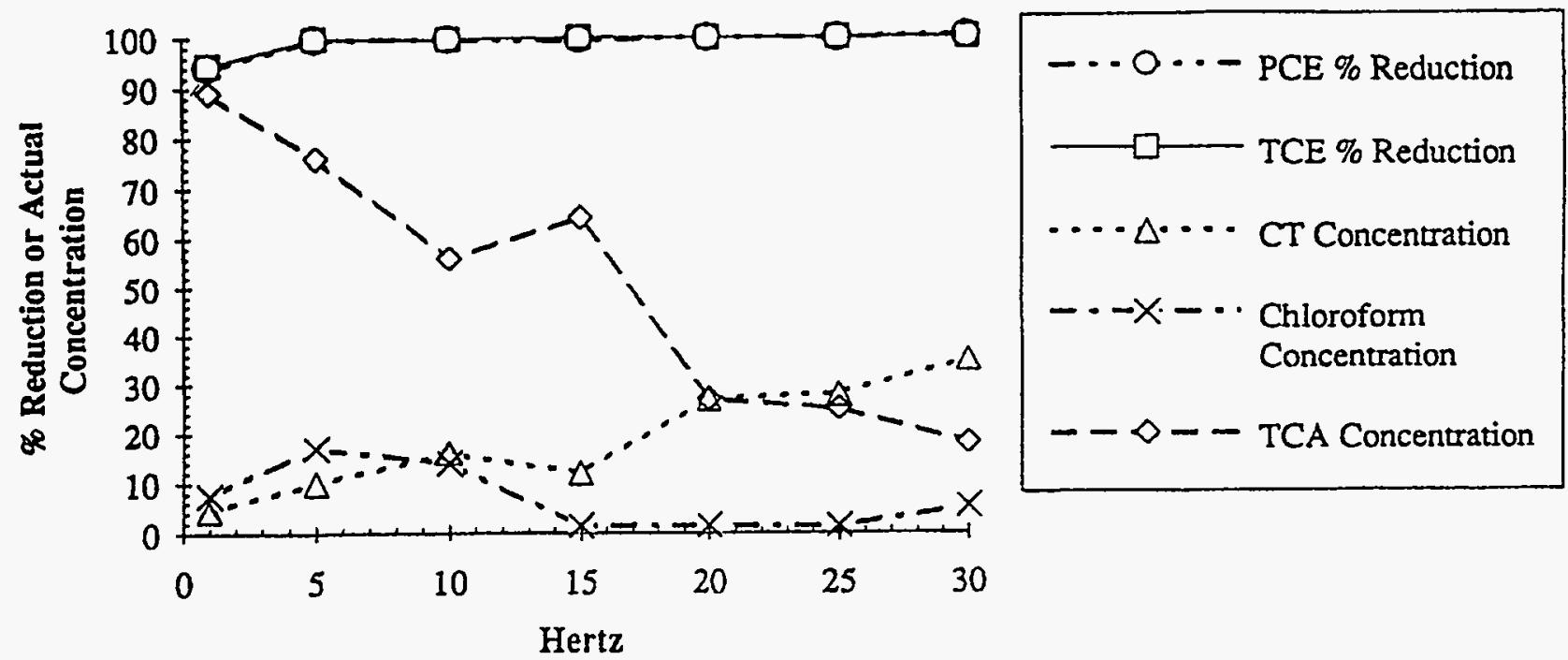

FIGURE 6 PCE, TCE, TCA, CT, and Chloroform for 3100-ppmv Nominal PCE Concentration at 25-scfm Gas Flow Rate 


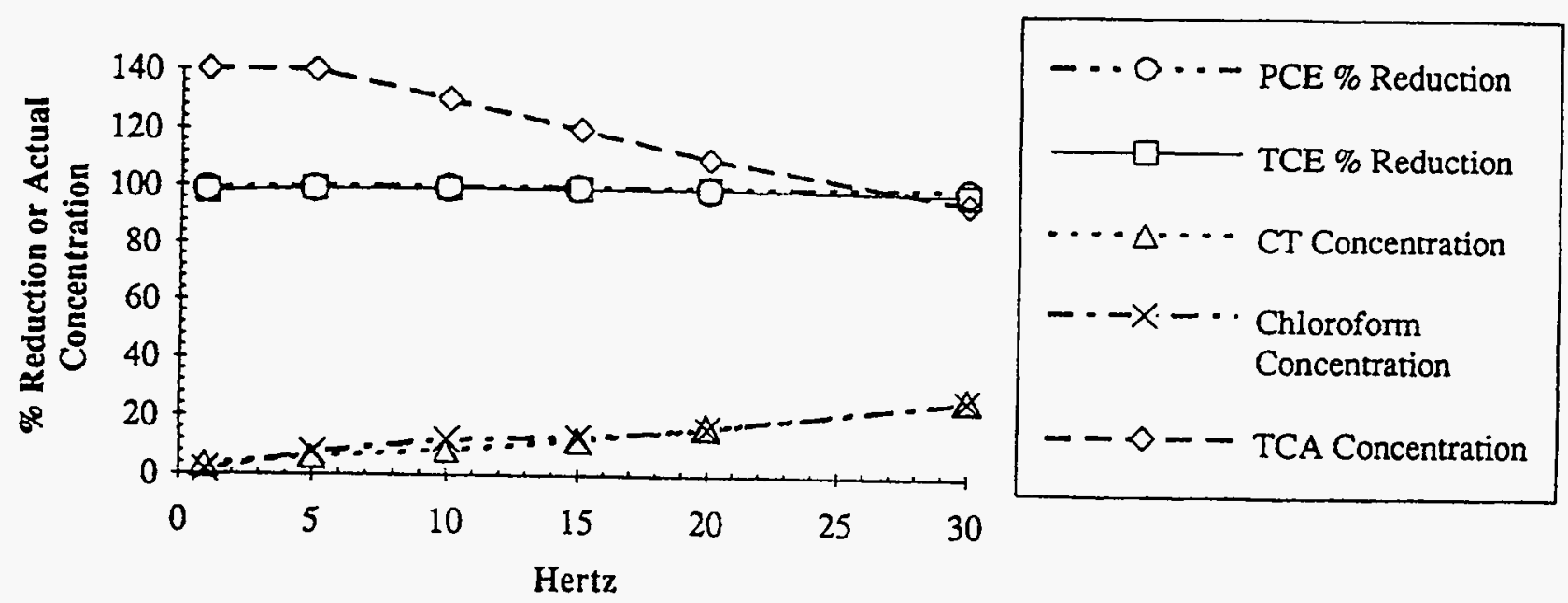

FIGURE 7 PCE, TCE, TCA, CT, and Chloroform for 450-ppmv Nominal PCE Concentration at 50-scfm Gas Flow Rate
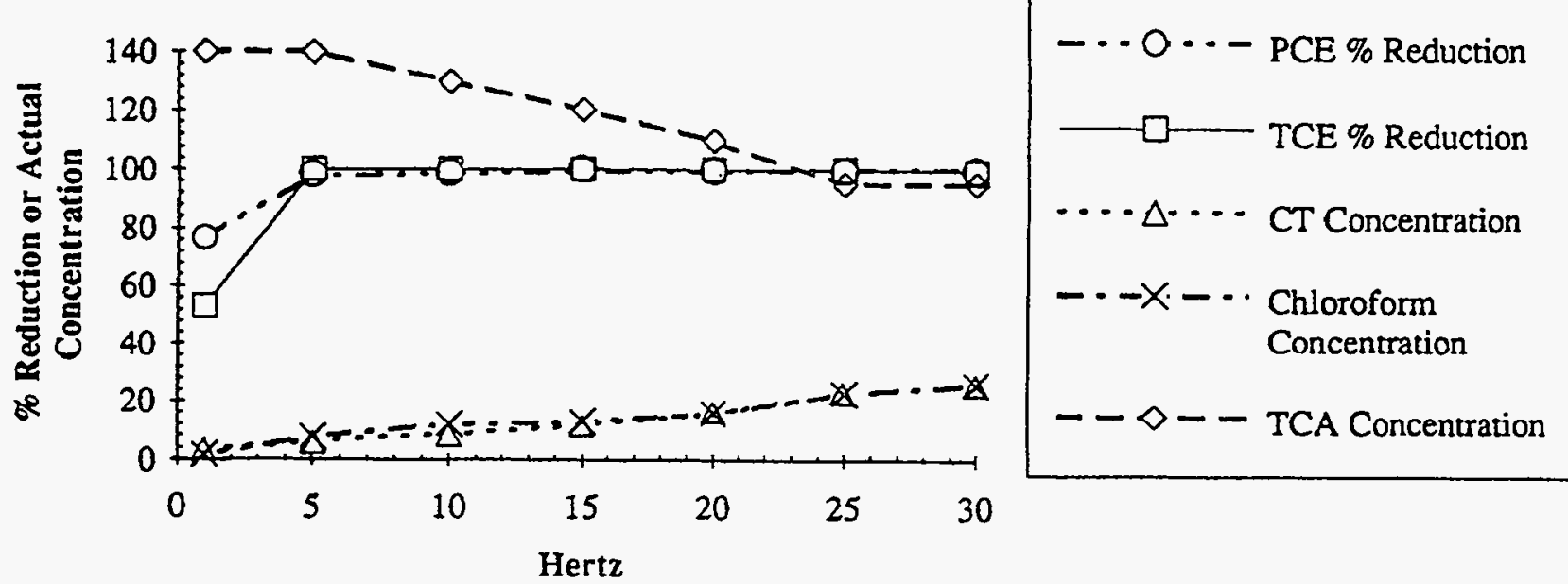

FIGURE 8 PCE, TCE, TCA, CT, and Chloroform for 5000-ppmv Nominal PCE Concentration at 75-scim Gas Flow Rate 


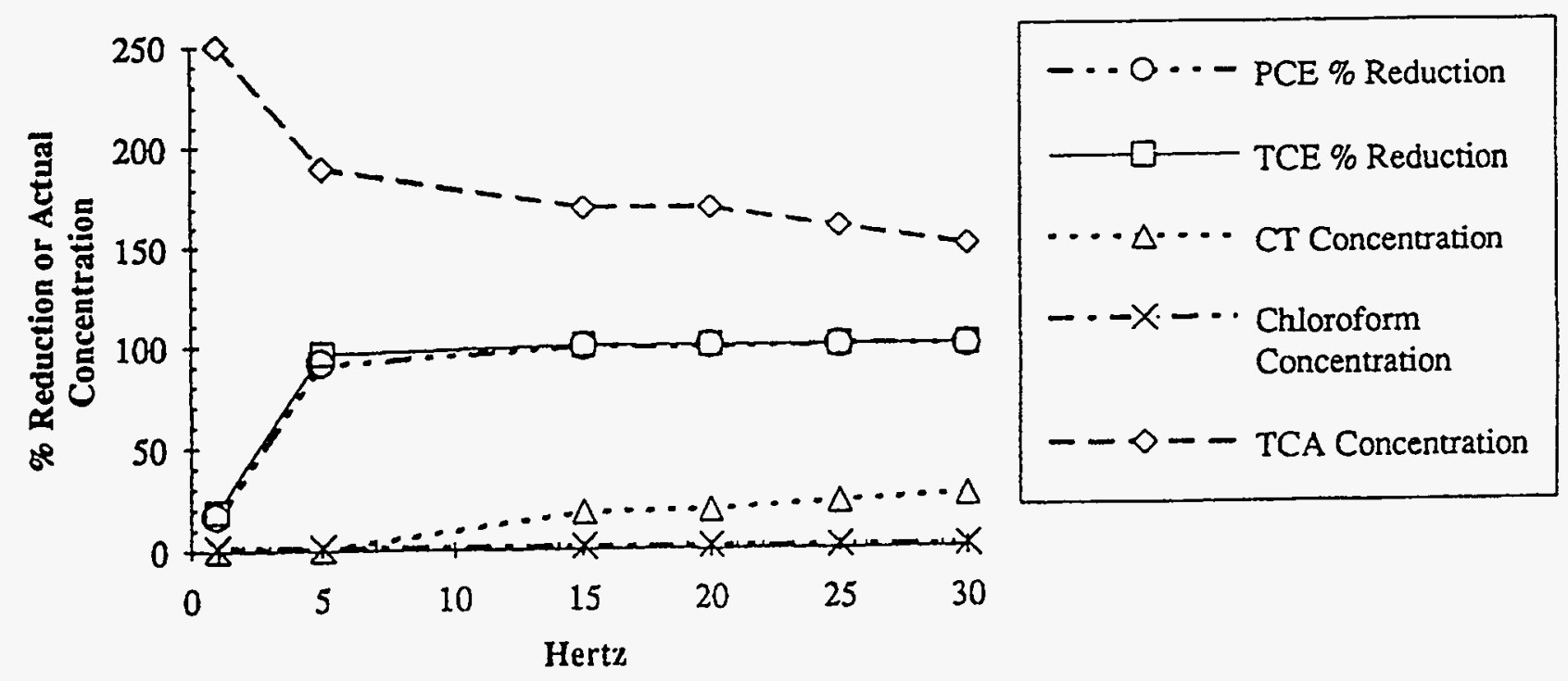

FIGURE 9 PCE, TCE, TCA, CT, and Chloroform for 4450-ppmv Nominal PCE Concentration at 80-scfm Gas Flow Rate

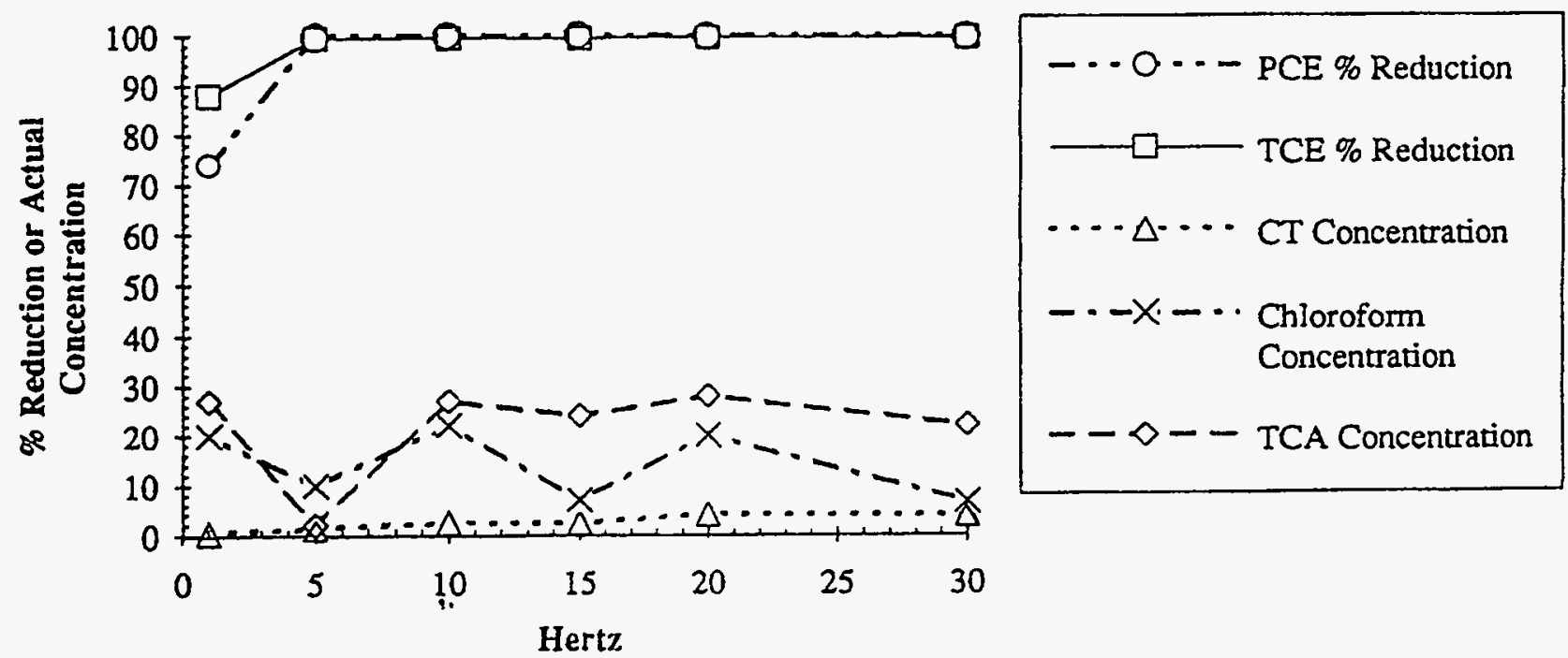

FIGURE 10 PCE, TCE, TCA, CT, and Chloroform for 800-ppmv Nominal PCE Concentration at 100-scfm Gas Flow Rate 

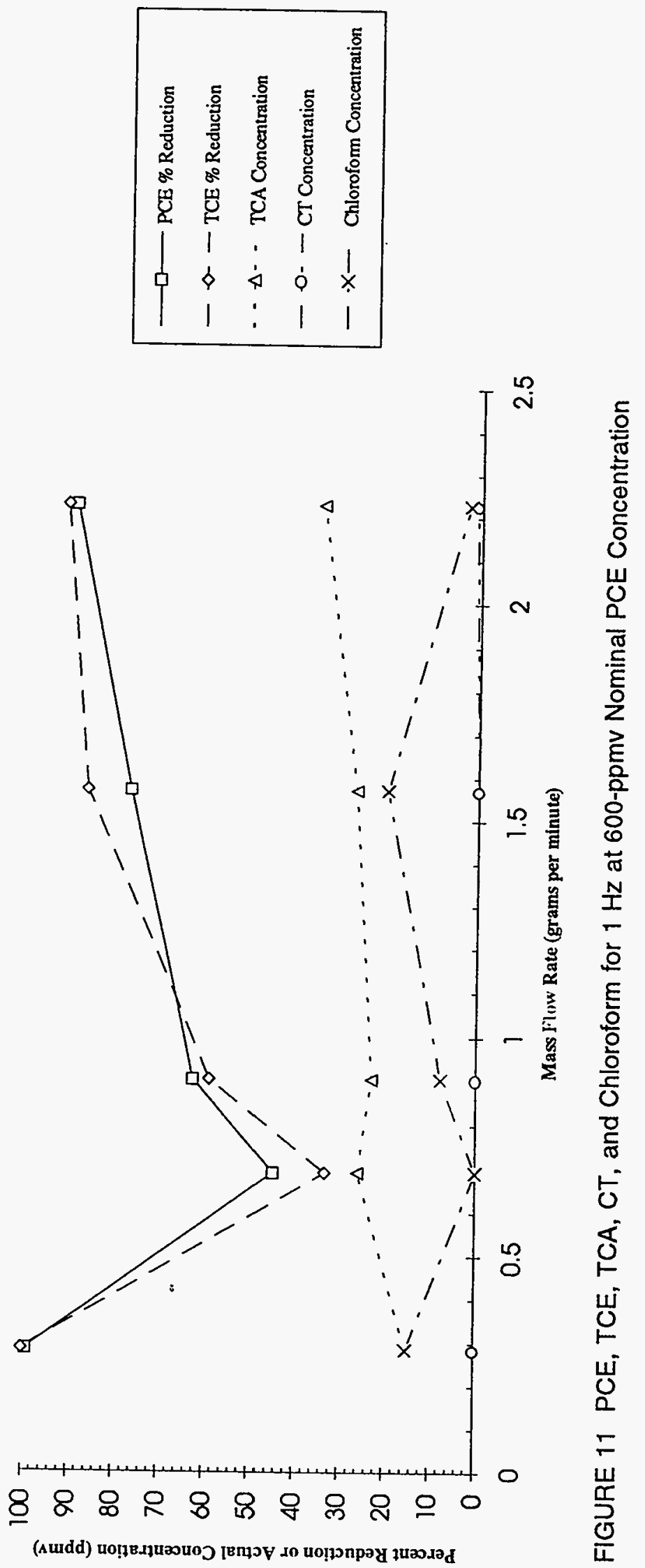

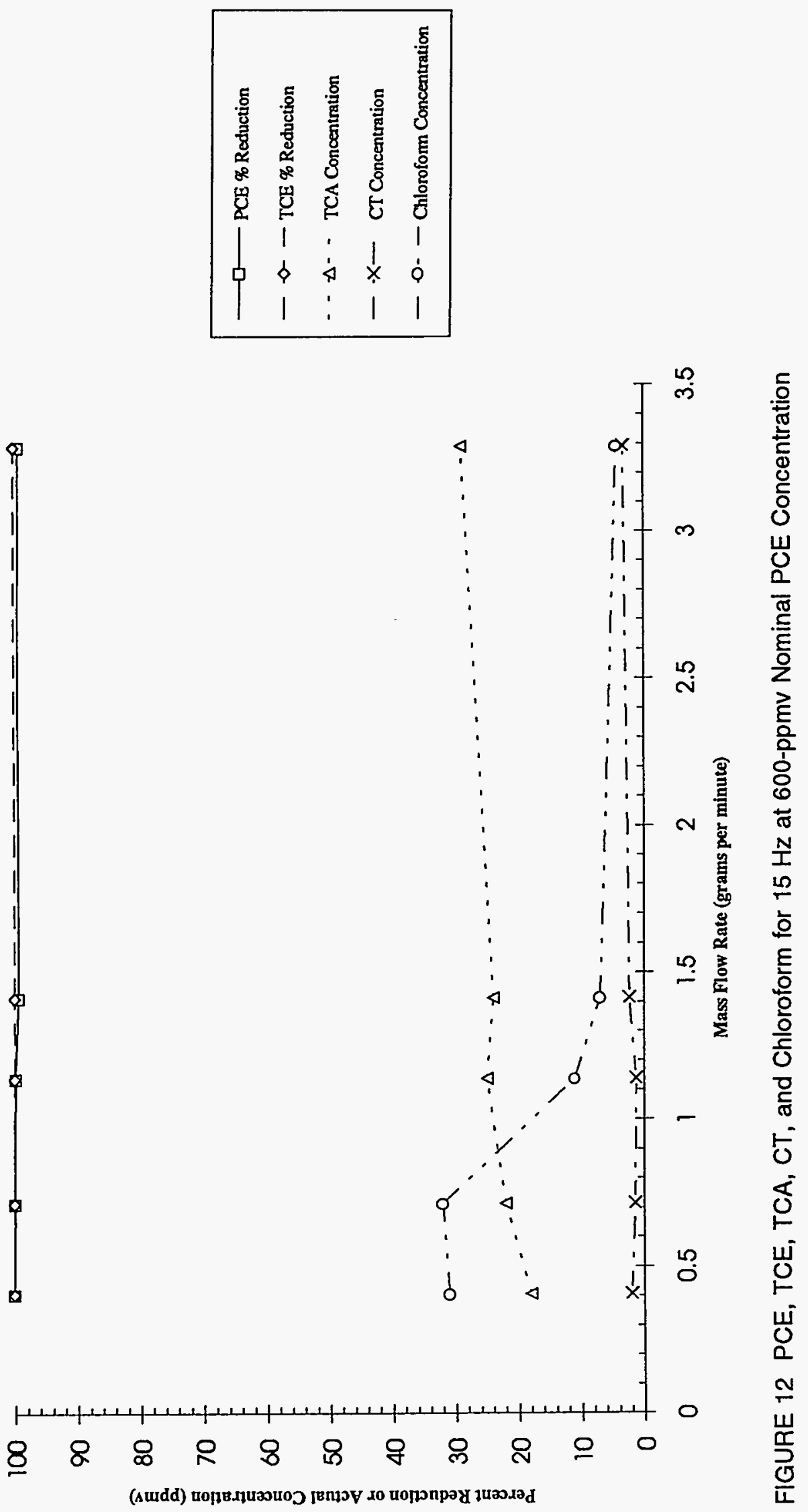


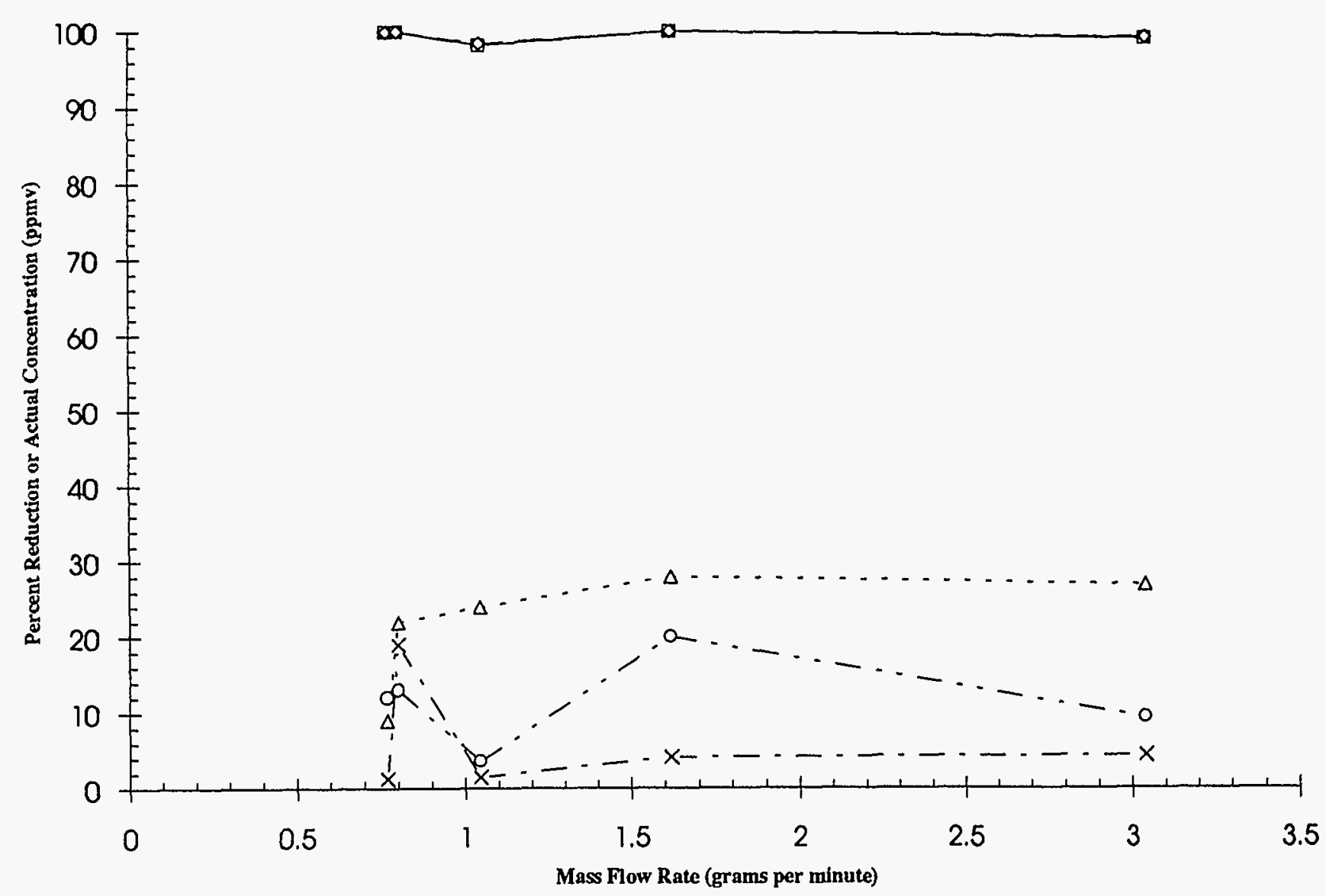

$-\square-$ PCE \% Reduction
$-\diamond-$ TCE $\%$ Reduction
$-\Delta-$ TCA Concentration
$-\times-$ CT Concentration
$-0--$ Chloroform Concentration

FIGURE 13 PCE, TCE, TCA, CT, and Chloroform for $20 \mathrm{~Hz}$ at 600-ppmv Nominal PCE Concentration 


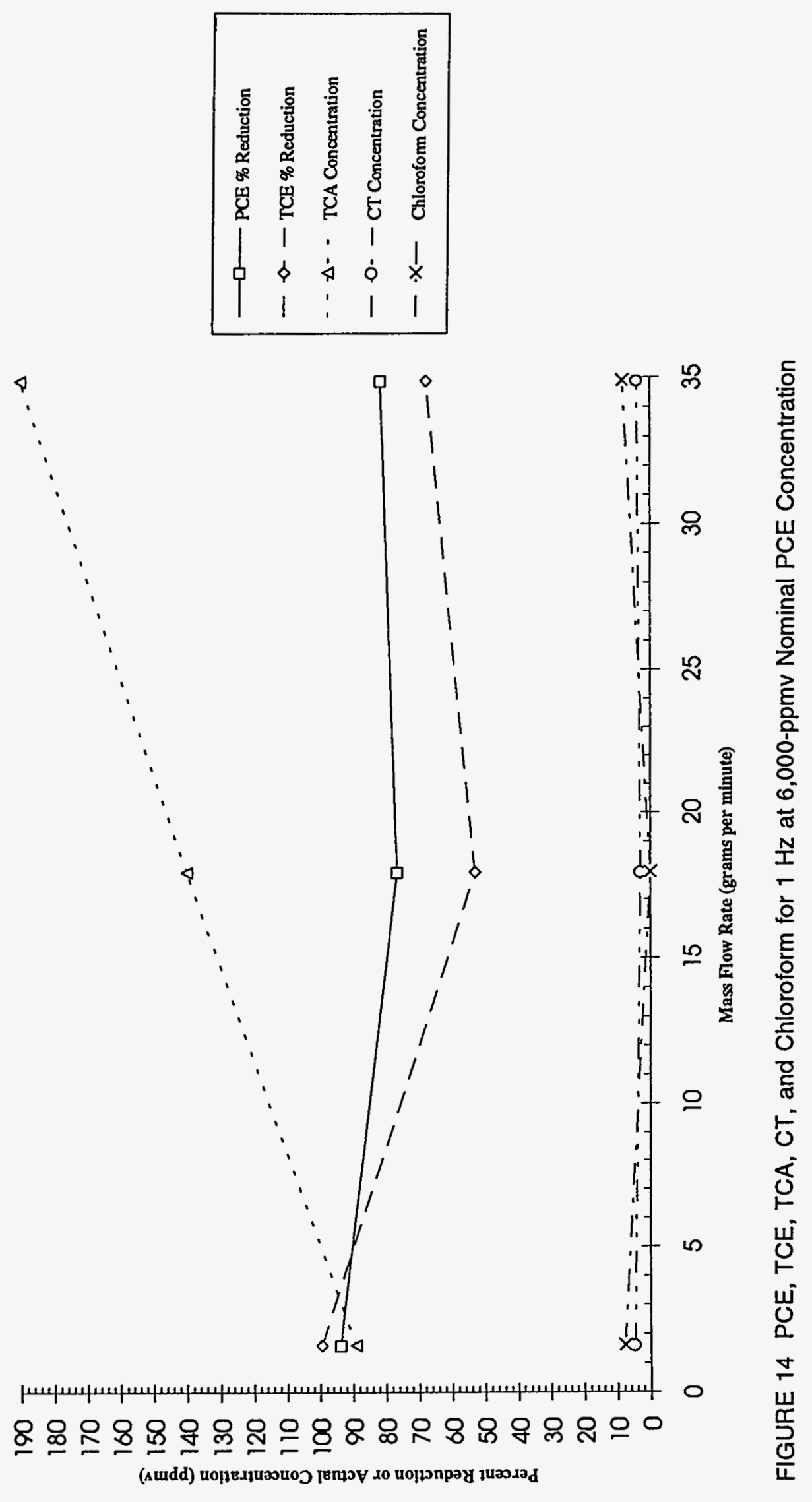



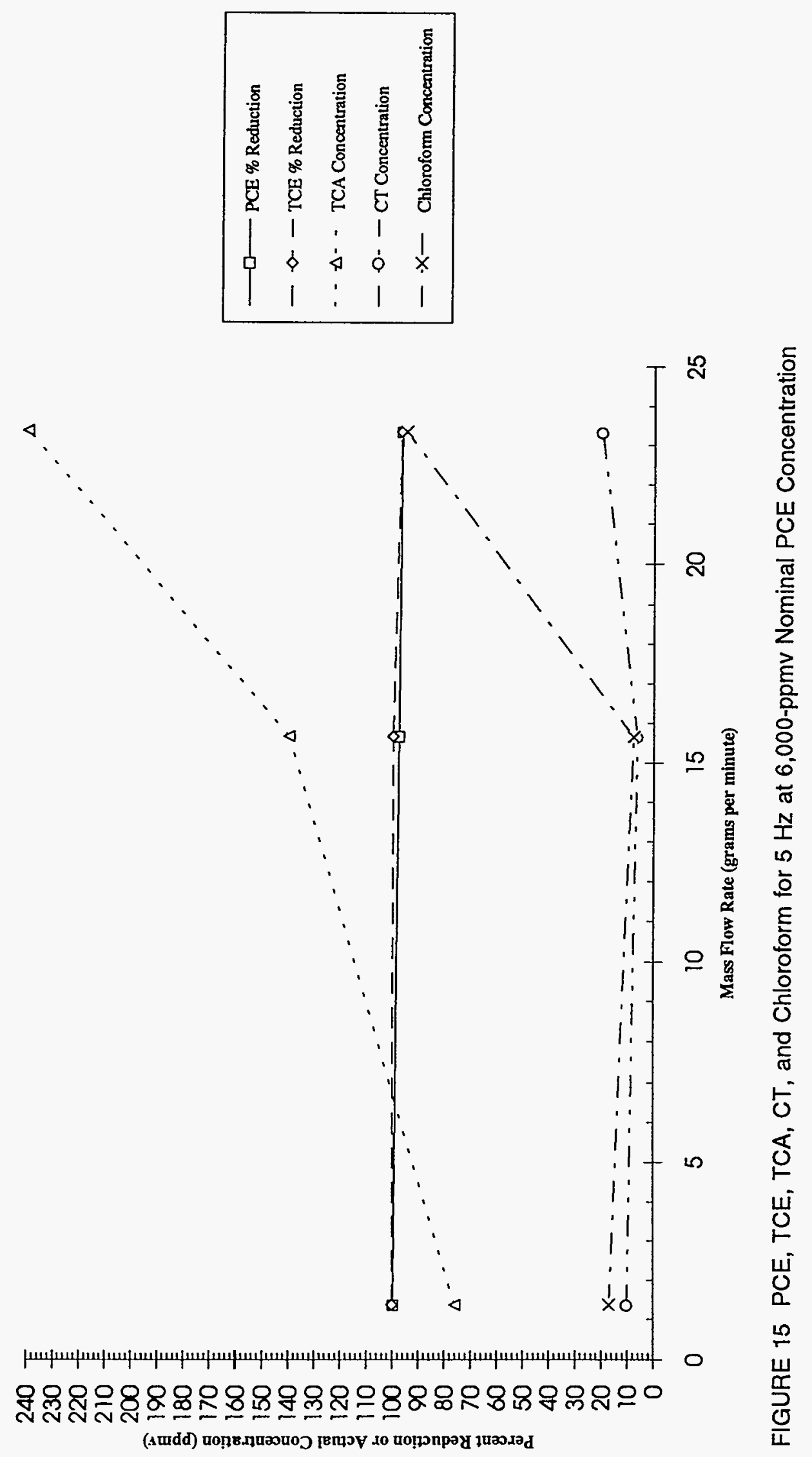


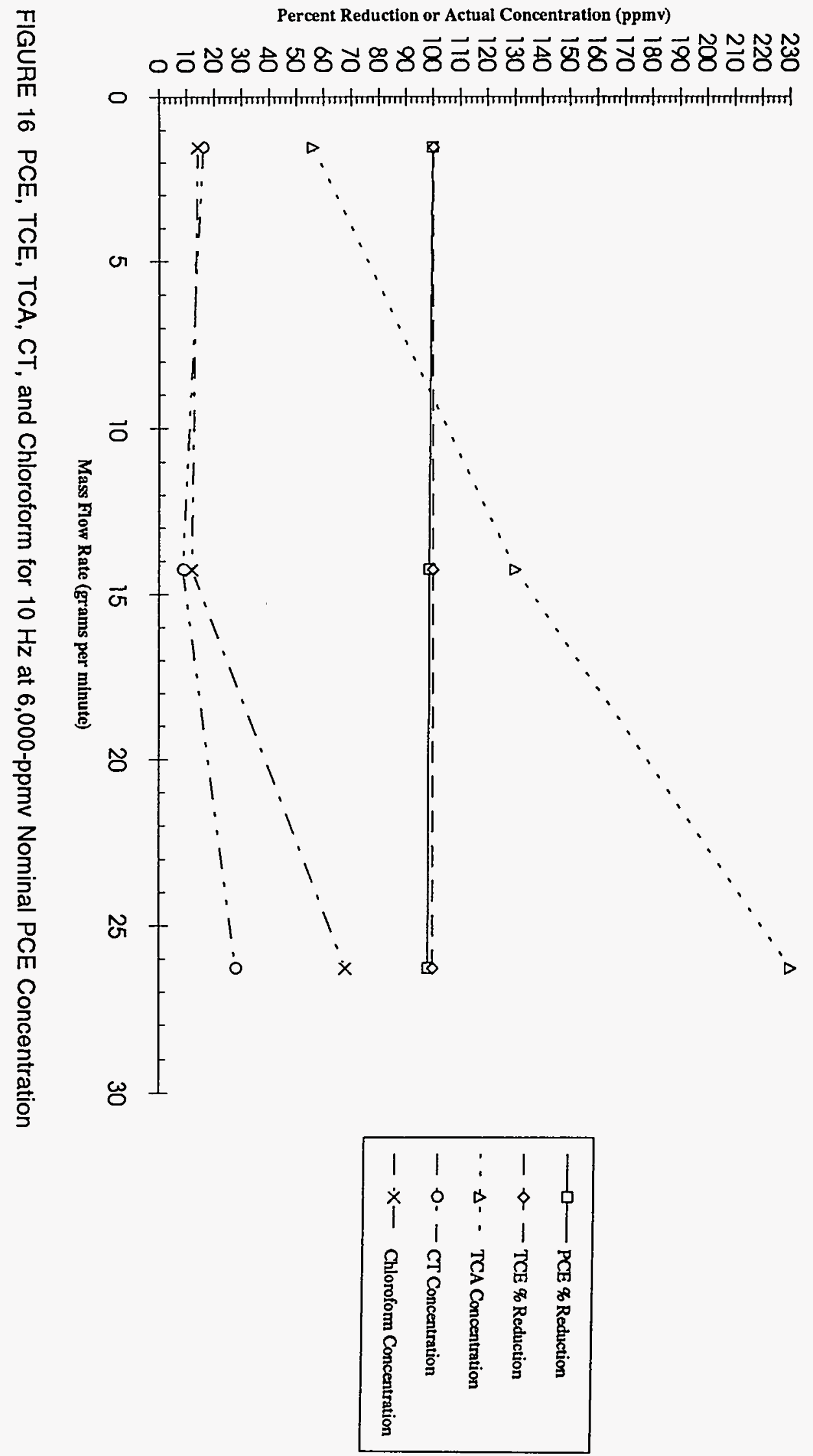


until the $25-\mathrm{Hz}$ range, and then remains constant in the $25-$ to $30-\mathrm{Hz}$ range. The $\mathrm{CT}$ concentration rises slightly throughout the $5-$ to $15-\mathrm{Hz}$ range. The chloroform concentration increases over the 1 - to $30-\mathrm{Hz}$ range.

Figure 9 is similar to Figure 8 ( $80 \mathrm{scfm}$ and 4450 ppmv for Figure 9, as compared to $75 \mathrm{scfm}$ and $5000 \mathrm{ppmv}$ for Figure 8). Both the TCE and PCE are effectively destroyed at all of the flash-lamp rates beyond $5 \mathrm{~Hz}$. At the $1-\mathrm{Hz}$ level, only about $20 \%$ of the PCE and TCE are destroyed. The TCA concentration drops off steadily throughout the full range of hertz values. The CT concentration rises slightly throughout the $1-$ to $30-\mathrm{Hz}$ range. The chloroform concentration remains at its very low level throughout the full range of hertz values.

Figure 10 shows that at an inlet concentration of 800 ppmv for PCE and with a $100-s c f m$ gas flow rate, both the TCE and PCE are effectively destroyed at all of the flash-lamp rates beyond $5 \mathrm{~Hz}$. At the $1-\mathrm{Hz}$ level, about $74 \%$ of the PCE is destroyed and about $88 \%$ of the TCE is destroyed. In contrast to Figure 8, the outlet TCA concentration here increases only slightly throughout the $1-$ to $30-\mathrm{Hz}$ range. The $\mathrm{CT}$ concentration shows a slightly decreasing trend in the 1 - to $30-\mathrm{Hz}$ range. The chloroform concentration ranges between 10 and $20 \mathrm{ppmv}$.

Figures 11 through 16 attempt to account for the mass of the contaminants that the Purus system actually encounters. The mass takes into account the flow rate and the concentration of the contaminant, as well as the molecular weight of the contaminant. Figures 11 through 13 show the impact of increasing the flash-lamp frequency $(1,15$, and $20 \mathrm{~Hz})$ on a single nominal concentration of 600 ppmv for various flow rates (increasing the mass of the contaminants that the Purus system encounters). Figures 14 through 16 show the impact of increasing the flash-lamp frequency $(1,5$, and $10 \mathrm{~Hz})$ on a much higher nominal concentration of $6000 \mathrm{ppmv}$ for various flow (mass) rates.

Figure 11 shows that at an inlet concentration of $600 \mathrm{ppmv}$ for PCE and with a $1-\mathrm{Hz}$ flash-lamp frequency, both the TCE and PCE are effectively destroyed at only the lowest mass. The destruction of PCE and TCE drops off markedly for the next two data points and finally recovers into the 75 to $90 \%$ range for higher-mass values. The TCA concentration increases only slightly throughout the range of mass data points. The CT concentration remains at nominally zero throughout the full range of mass values. The chloroform concentration decreases at the second data point, peaks in the middle of the mass values, and then tails off at the highest values.

Figure 12 shows that at the same nominal inlet concentration (600 ppmv for PCE) and $15 \mathrm{~Hz}$, both the TCE and PCE are effectively destroyed at all concentration/flow rates (mass). The TCA concentration increases only slightly throughout the range of mass data points. The CT concentration remains basically constant (at very low level) throughout the full range of mass values. The chloroform concentration increases at the second data point, then tapers off slightly throughout the remaining values. 
Figure 13 shows that at the same nominal inlet concentration (600 ppmv for PCE) and $20 \mathrm{~Hz}$, both the TCE and PCE are effectively destroyed at all concentration/flow rates (mass). The TCA concentration starts off low and rises for the second and third data points before leveling off throughout the remaining values. The $\mathrm{CT}$ concentration starts off at zero and rises only slightly throughout the mass values. The chloroform concentration is similar to the $15-\mathrm{Hz}$ pattern, except that in the middle of the mass values it increases before going down at the highest value.

The trends indicated in Figures 11 through 13 indicate that at low concentrations/flow rates (mass), there is some variability in all of the PCE, TCE, TCA, CT, and chloroform concentrations. At the higher mass values, the concentrations of all five of the contaminants seem to be more constant.

Figure 14 indicates that at an inlet concentration of $6000 \mathrm{ppmv}$ for $\mathrm{PCE}$ and a $1-\mathrm{Hz}$ flashlamp frequency, both the TCE and PCE are effectively destroyed at only the lowest mass. At the higher flow rates, the destruction of both PCE and TCE is in the 80 to $90 \%$ range. The TCA concentration increases almost twofold throughout the range of mass-data points. The CT and chloroform concentrations remain at very low values throughout the full range of mass values.

Figure 15 indicates that at the same nominal inlet concentration (6000 ppmv for PCE) and a 5-Hz flash-lamp frequency, both the TCE and PCE are effectively destroyed, at greater than $95 \%$ destruction, across the entire range of mass values. The TCA concentration increases about threefold throughout the range of mass-data points. Both the CT and chloroform concentrations are similar to those in Figure 14, except that at the highest flow rates both exhibit a marked increase in concentration.

Figure 16 (nominal inlet concentration $6000 \mathrm{ppmv}$ for PCE, 10-Hz flash-lamp frequency) is very similar to Figure 15, except that the $\mathrm{CT}$ and chloroform concentrations do not increase quite as much at the highest flow rates.

The trends indicated in Figures 14 through 16 indicate that at low concentrations/flow rates (mass) both PCE and TCE are effectively destroyed. At higher mass values, the Purus system still destroyed $95 \%$ of both the PCE and TCE above $5 \mathrm{~Hz}$. The sharp increase in both the CT and chloroform concentrations at the higher hertz values and highest mass values would seem to indicate that the Purus process is actually producing more of these compounds as by-products of the internal photochemical reactions. 


\subsection{Chemical Reactions of Primary and Secondary Contaminants}

The two main chemical contaminants in the soil at SRS are TCE and PCE. TCA is present in lesser amounts. When TCE undergoes photo-oxidation, it produces a chain reaction, with the quantum yield equaling approximately 31 (Blystone et al. 1991). The equations presented below were deduced from experiments done in a spectrophotometer cell.

TCE photo-induced chain reaction (where $h v=$ light):

$\mathrm{HClC}=\mathrm{CCl}_{2}+\mathrm{h} v \rightarrow \mathrm{HClC}=\mathrm{CCl}^{\bullet}+\mathrm{Cl}^{\bullet}$

$\mathrm{Cl}^{\circ}+\mathrm{HClC}=\mathrm{CCl}_{2} \rightarrow \mathrm{HCl}_{2} \mathrm{C}-\mathrm{CCl}_{2}$

$\mathrm{HCl}_{2} \mathrm{C}-\mathrm{CCl}_{2}{ }^{\circ}+\mathrm{O}_{2} \rightarrow \mathrm{HCl}_{2} \mathrm{C}-\mathrm{CCl}_{2} \mathrm{OO}$

$2 \mathrm{HCl}_{2}-\mathrm{C}-\mathrm{CCl}_{2} \mathrm{OO} \rightarrow 2 \mathrm{HCl}_{2} \mathrm{CCl}_{2} \mathrm{O}^{*}+\mathrm{O}_{2}$

$\mathrm{HCl}_{2} \mathrm{C}-\mathrm{CCl}_{2} \mathrm{O}^{*} \rightarrow \mathrm{HCl}_{2} \mathrm{C}-\mathrm{CClO}+\mathrm{Cl}^{\bullet} \rightarrow$ further products

(DCAC)

DCAC, the first stable intermediate by-product, accounts for more than $90 \%$ of the TCE consumed. Similarly, it is expected that trichloroacetyl chloride (TCAC) is the first stable intermediate produced from PCE.

Further testing performed in the spectrophotometer cell showed that, as the photolysis continued, DCAC began to degrade as well, even though the rates were 10 to 100 times lower than those observed for TCE and PCE.

DCAC degradation:

hv $+\mathrm{HCl}_{2} \mathrm{C}-\mathrm{CClO} \rightarrow \mathrm{Cl}_{2} \mathrm{HC}-\mathrm{C}^{\bullet} \mathrm{O}+\mathrm{Cl}^{\bullet}$

$\mathrm{Cl}_{2} \mathrm{HC}-\mathrm{C}^{\circ} \mathrm{O}+\mathrm{O}_{2} \rightarrow \mathrm{Cl}_{2} \mathrm{HC}-\mathrm{C}(\mathrm{O}) \mathrm{OO}^{*}$

$2 \mathrm{Cl}_{2} \mathrm{HC}-\mathrm{C}(\mathrm{O}) \mathrm{OO}^{*} \rightarrow \mathrm{O}_{2}+2 \mathrm{Cl}_{2} \mathrm{HC}-\mathrm{C}(\mathrm{O}) \mathrm{O}^{*}$

$\mathrm{Cl}_{2} \mathrm{HC}-\mathrm{C}(\mathrm{O}) \mathrm{O}^{*} \rightarrow \mathrm{Cl}_{2} \mathrm{HC}^{\bullet}+\mathrm{CO}_{2}$

$\mathrm{Cl}_{2} \mathrm{HC}^{\bullet}+\mathrm{O}_{2} \rightarrow \mathrm{Cl}_{2} \mathrm{HCOO}^{*}$

$2 \mathrm{Cl}_{2} \mathrm{HCOO}^{\circ} \rightarrow \mathrm{O}_{2}+2 \mathrm{Cl}_{2} \mathrm{HCO}^{*}$

$\mathrm{Cl}_{2} \mathrm{HCO}^{*} \rightarrow \mathrm{ClHCO}+\mathrm{Cl}^{*}$

The final products of this reaction appear to be carbon dioxide, formyl chloride ( $\mathrm{ClHCO}$ ), and hydrogen chloride, but this may not be the only pathway. When DCAC was the starting compound in the spectrophotometer cell and chlorine gas $\left(\mathrm{Cl}_{2}\right)$ was added, the yield of DCC (phosgene) increased, suggesting that DCC yields resulted from chlorine atom attacks on DCAC. 
Further DCAC degradation:

$\mathrm{HCl}_{2} \mathrm{C}-\mathrm{CClO}+\mathrm{Cl}^{\bullet} \rightarrow \mathrm{ClOC}-\mathrm{Cl}_{2} \mathrm{C}^{\bullet}+\mathrm{HCl}$

$\mathrm{ClOC}-\mathrm{Cl}_{2} \mathrm{C}^{\bullet}+\mathrm{O}_{2} \rightarrow \mathrm{ClOC}-\mathrm{Cl}_{2} \mathrm{COO} \cdot$

$2 \mathrm{ClOC}-\mathrm{Cl}_{2} \mathrm{COO}^{\circ} \rightarrow \mathrm{O}_{2}+2 \mathrm{ClOC}-\mathrm{Cl}_{2} \mathrm{CO}^{*}$

$\mathrm{ClOC}-\mathrm{Cl}_{2} \mathrm{CO} \rightarrow \mathrm{Cl}_{2} \mathrm{CO}+\mathrm{OClC} \rightarrow$ further products (DCC)

The reduction of TCA is believed to be as follows (Blystone et al. 1991). This is not a chain reaction.

TCA nonchain photolysis:

$\mathrm{H}_{3} \mathrm{C}-\mathrm{CCl}_{3}+\mathrm{hv} \rightarrow \mathrm{H}_{3} \mathrm{C}-\mathrm{CCl}_{2}+\mathrm{Cl}^{\bullet}$

$\mathrm{H}_{3} \mathrm{C}-\mathrm{CCl}_{2}+\mathrm{O}_{2} \rightarrow \mathrm{H}_{2} \mathrm{C}=\mathrm{CCl}_{2}+\mathrm{HO}_{2} \cdot$

$\mathrm{Cl}^{\circ}+\mathrm{Cl}_{3} \mathrm{C}-\mathrm{CH}_{3} \rightarrow \mathrm{Cl}_{3} \mathrm{C}-\mathrm{CH}_{2}+\mathrm{HCl}$

$\mathrm{Cl}_{3} \mathrm{C}^{-} \mathrm{CH}_{2}+\mathrm{O}_{2} \rightarrow \mathrm{Cl}_{3} \mathrm{C}-\mathrm{CH}_{2} \mathrm{OO}$

$2 \mathrm{Cl}_{3} \mathrm{C}-\mathrm{CH}_{2} \mathrm{OO} \rightarrow 2 \mathrm{Cl}_{3} \mathrm{C}-\mathrm{CH}_{2} \mathrm{O}^{*}+\mathrm{O}_{2}$

$\mathrm{Cl}_{3} \mathrm{C}-\mathrm{CH}_{2} \mathrm{O}^{\bullet}+\mathrm{O}_{2} \rightarrow \mathrm{Cl}_{3} \mathrm{C}-\mathrm{CHO}+\mathrm{HO}_{2} \cdot \rightarrow \rightarrow$ trichloroacetic acid (TCAA)

In the field studies performed at Lawrence Livermore, $86 \mathrm{~mol} \%$ of TCE broke down into DCAC, and $6.9 \mathrm{~mol} \%$ broke down into DCC at a $1.2-\mathrm{kJ}$ dose. At a 70-kJ dose, DCAC accounted for $28 \mathrm{~mol} \%$ and DCC for $23 \mathrm{~mol} \%$. The dose was calculated with the following equation:

$$
\text { Dose }=\text { Residence time } \times \text { Flash frequency } \times \text { No. of lamps } \times \text { Energy } / \text { flash }
$$

As the dose increased, DCC increased and DCAC decreased. The changes in the concentrations were not equal, though. It is believed that the DCAC reduction followed more than one pathway. 


\section{Economics of Purus System}

The following economic analysis is based on the operation costs for the removal of TCE and PCE only. Under the assumed conditions, complete mineralization would require substantially more power. The removal of both TCA and the initial photooxidation products from TCE and PCE require much more power (i.e., longer exposure) than the power required for converting the starting materials. This is because the efficient chain reactions apply only to the first steps, and the initial photooxidation products accumulate and act just like any other compound (e.g., TCA) that is not subject to chain reactions.

The Purus FP-3 UV-irradiation unit consumes approximately $200 \mathrm{~W}$ of electrical power for computer and control functions. In addition, each lamp consumes $480 \mathrm{~W}$ of electrical power to sustain the simmer arc needed for operation between flashes. Each flash of each lamp uses an additional $153 \mathrm{~W}$ of power.

The total power consumption is equal to computer and control power plus simmer power per lamp times the number of operating lamps plus flash energy per lamp times the number of lamps operating times the flash rate (number of flashes per second):

$$
\begin{aligned}
\text { Total Power }= & (\text { Computer and Control Power })+(\text { Simmer Power per Lamp })(\text { Number of Lamps }) \\
& +(\text { Energy per Flash })(\text { Number of Lamps })(\text { Flash Rate })
\end{aligned}
$$

Substituting the constraints, this becomes:

$$
\text { Total Power }=200 \mathrm{~W}+[480 \mathrm{~W}+(153 \mathrm{~W}) \text { (Flash Rate })] \text { (Number of Lamps) }
$$

Total power is converted into kilowatt-hours ( $\mathrm{kWh}$ ) by dividing by 1,000 (to convert from watts to kilowatts) and multiplying by the operating time in hours.

The operating cost is obtained by multiplying the total energy consumption (in kilowatthours) from the above calculation by an assumed electrical cost (typically assumed to be $\$ 0.10 / \mathrm{kWh}$.

As an example, calculations for two lamps operating at 15 flashes per second $(15 \mathrm{~Hz})$ for one hour yield the following:

$$
\text { Total Power }=200 \mathrm{~W}+[480 \mathrm{~W}+(153 \mathrm{~W})(15)](2)=5,750 \mathrm{~W}
$$

$$
\text { Electrical Operating Cost }=(5,750 \mathrm{~W} / 1,000)(\$ 0.10)=\$ 0.575 \text { per hour }
$$


Consumables, such as lamps, are estimated at $\$ 250$ per lamp, with a life expectancy of 1,000 hours at full power $(30 \mathrm{~Hz})$. This is equal to $\$ 0.25$ per hour per lamp at $30 \mathrm{~Hz}$. In the above example, each lamp was operating at half power $(15 \mathrm{~Hz})$, costing $\$ 0.125$ per lamp. With two lamps operating, we calculate $\$ 0.25$ per hour. Other components with finite life add approximately $10 \%$ of this value, or $\$ 0.025$, for a total operating cost of $\$ 0.575+\$ 0.25+$ $\$ 0.025$, or $\$ 0.85$ per hour.

The cost of equipment demonstrated in this program (without an auxiliary water cooler) was approximately $\$ 150,000$. 


\section{Conclusions}

On the basis of the experimental data, a few conclusions may be drawn for the original contaminants and for the reaction products of the experimental procedure. TCE is effectively destroyed to below the detection limit at or beyond $3 \mathrm{~Hz}$ for all of the tested flow rates and nominal concentrations. More often than not, the TCE was totally $(\geq 98 \%)$ destroyed at $3 \mathrm{~Hz}$. The PCE results track the TCE results very closely, except for the fact that the PCE is effectively destroyed to below the detection limit to an equal or lesser degree than the TCE. The PCE is effectively destroyed in every case by $5 \mathrm{~Hz}$.

As for the products of the reaction, they seem very unpredictable. One of these products, the TCA concentration, decreases for some flow rates and increases for others. There are also some experiments in which the TCA both increases and decreases as the pulse rate increases. As of yet, no pattern is discernible for the TCA.

Another of the products is chloroform. The chloroform concentration in these experiments remained fairly stable for all experimental values tested. There were minor deviations in the chloroform concentrations, but the overall concentration was never greater than about $15 \mathrm{ppm}$.

The last product that was under study was carbon tetrachloride. The CT concentration showed no general trend; again, it either increased or decreased with an increase in pulse rate, as the flow and concentrations dictated. There were runs in which the carbon tetrachloride was destroyed, others in which it was created, and yet others in which the quantities were not changed.

Overall, the Purus system had no trouble destroying the TCE and PCE at low inlet concentrations and at low flow rates. Only at the lowest flash-lamp rates (below $5 \mathrm{~Hz}$ ) were the TCE and PCE not destroyed completely. Only at the highest mass-flow rates (concentrations above $6000 \mathrm{ppmv}$ and the highest scfm) did the Purus unit have difficulty destroying all of the PCE and TCE. Even then, 80 to $90 \%$ of the PCE and TCE was destroyed. One concern was that both the chloroform and CT concentrations increased significantly under these high-flow, highinlet concentrations. The removal of both TCA and the initial photooxidation products from TCE and PCE require much more power (i.e., longer exposure) than the power required for converting the starting materials. This is because the efficient chain reactions apply only to the first steps, and the initial photooxidation products accumulate and act just like any other compound (e.g., TCA) that is not subject to chain reactions.

The Purus UV-irradiation system, because of very rapid chain reactions, appears to provide a cost-efficient means of removing PCE and TCE from air streams generated from soil vapor extraction and other methods. However, this system provided only limited removal of by-product TCA under the conditions tested. Previous work (Blystone et al. 1991) showed that the major initial by-products of TCE and PCE photo-oxidation are the highly toxic compounds DCAC and TCAC, which photoreact further to DCC and eventually to $\mathrm{HCl}, \mathrm{CO}_{2}$, and probably formyl chloride. These initial by-products (like TCA) require much longer exposures for complete conversions than do PCE and TCE. Taking practical, economic advantage of the efficient chain 
reactions can be done only if the initial products can be cheaply removed. Because DCAC, DCC, and TCAC are reactive and hydrolyze easily to DCAA, $\mathrm{CO}_{2}$, and TCAA, respectively, a promising approach would involve some form of alkaline scrubbing to concentrate the product gases, followed by thermal or biological treatment of the haloacetic acids or salts produced. 


\section{References}

Blystone, P.G., et al., 1991, "Advanced Ultraviolet Flashlamps for the Destruction of Organic Contaminants in Air," presented at the American Chemical Society Industrial and Engineering Chemistry Division Special Symposium, Atlanta, Ga., Oct. 1-3.

Hazen, T.C., 1991, "Test Plan for In Situ Bioremediation Demonstration of the Savannah River Integrated Demonstration Project DOE/OTD TTP No.: SR 0566-01 (U)," Westinghouse Savannah River Company, Aiken, S.C., Sept. 18, 1991; Revision 3: April 23, 1992, report WSRC-RD91-23.

Marine, I.W., and H.W. Bledsoe, 1984, "Supplemental Technical Data Summary: M-Area Groundwater Investigation," E.I. DuPont de Nemours and Company, Savannah River Laboratory, Aiken, S.C., DPSTD-84-112. 